\title{
Improving Korea's Climate Finance for Developing \\ Countries: Policy Analysis of the Management of Climate-Related Development Finance (CRDF)
}

\begin{abstract}
No country can be free of global warming and incremental natural disasters. This is true especially of developing countries, which are the most vulnerable to climate change. Although developed and developing countries agreed to mobilize USD 100 billion per year to support developing countries by 2020, the Organization for Economic Cooperation and Development (OECD) has transferred only about USD 58.5 billion, on average over 2015 to 2018, to developing countries. Korea, one of the OECD's Development Assistance Committee (DAC) members, has a considerable gap between its contribution and its target. This is due to several reasons such as the lack of official development assistance (ODA) as a primary public resource for developing
\end{abstract}

Corresponding author: Youngwoo Kim (Director, Performance Management Team, KOICA, Korea) (kyw0490@koica.go.kr)

(c) Copyright Korea International Cooperation Agency. This is an Open-Access article distributed under the terms of the Creative Commons Attribution Non-Commercial License (http://creativecommons.org/ licenses/by-nc/4.0/) which permits unrestricted non-commercial use, distribution, and reproduction in any medium, provided the original work is properly cited. 


\section{Abstract}

countries, limitations of other forms of public climate finance, and the low level of public-private partnerships (PPP) related to climate change.

This study analyzes Korea's climate finance, mainly climate-related development finance (CRDF)) as a part of ODA. It suggests a strategy for solving the issues faced by the Korean government with a policy analysis approach.

Key words: Climate Change, Climate Finance, Official Development Assistance (ODA), Climate-Related Development Finance (CRDF), Public Private Partnership (PPP) 


\section{I . INTRODUCTION}

Every country faces global warming and incremental natural disasters, but developing countries are more vulnerable to climate change. One of the main concerns to deal with climate change issues is the lack of finance for developing countries. While the annual mobilizing target is USD 100 billion, the current average transfer from developed countries to developing countries is the only USD 58.5 billion from 2015 to 2018. The Organization for Economic Cooperation and Development (OECD) defines that Climate-related development finance (CRDF) is comprised of official development assistance (ODA), other official flows (OOF), and private investment for developing countries. However, in terms of data collection issues, ODA is the most substantial part of the current CRDF based on regular reports by Development Assistance Committee (DAC) countries.

Being the $8^{\text {th }}$ largest $\mathrm{CO}_{2}$ emitter globally, Korea does not fulfill its responsibility for supporting developing countries in that respect. Besides, the Korean government needs more cooperation with developing countries to meet its Nationally Determined Contribution (NDC) goal by 2030. However, the Korean government has not allocated a sufficient budget and could not adopt appropriate interventions to cooperate with developing countries. So, the Korean government needs a strategy to increase climate finance from public and private resources by endorsing effective policy measures.

Considering the amount of $\mathrm{CO}_{2}$ emissions of Korea, the Korean government needs to set a long-term goal of contributing $0.3 \%$ of ODA per gross national income (GNI), and 30\% of CRDF/ODA, by 2030. These rates of goals are approximately two times more than the results of 2018. However, there are several problems to hinder the mobilization of climate finance with some root causes: bureaucratic failure contributes to the fragmented implementation of CRDF from ODA; diffusion of authority in climate change policy implementation limits the government's capacity to manage public climate funds; while information asymmetry and the problem of uncertainty hinder private climate investment. This study analyzes Korea's climate finance, mainly CRDF as a part of ODA, and suggests a strategy for solving the Korean government's issues with a policy analysis approach. 


\section{CONTEXT OF THE PROBLEM}

\section{Background}

\section{1) Developing countries' vulnerability to climate change}

Climate change is a common challenge of our time; however, it affects poor and vulnerable people the most. The poor are more exposed to climate change risks, and "climate shocks result in higher relative losses for poorer populations, who are less equipped to recover from such extreme incidents" (OECD, 2018: 95). Furthermore, the losses from climate-related weather shocks will continue to grow in the future because of the accumulation of people and assets in high-risk areas, shocks that are more frequent and greater in scale, and the lack of proper financial protection tools (Campillo et al., 2017: 7). For example, in Peru, the occurrence of one additional natural disaster per year could cause a regional poverty rate increase of 16\%-20\% (OECD, 2018: 96).

\section{2) Development aid and climate finance for developing countries}

The overall volume of the ODA on a cash basis in 2018 was USD 164.4 billion, coming from member countries of the DAC, Arab countries, and non-DAC countries (OECD, 2019b: 7). Net ODA from DAC countries reached USD 149.3 billion, $0.31 \%$ of GNI, representing a fall of $2.7 \%$ in real terms compared to 2017 due to the reduced spending on in-donor refugee costs for many DAC members (OECD, 2019b: 2). In parallel, as climate change accelerates, the needs for climate finance have increased. In the Paris Agreement in 2015, the countries agreed that "developed country parties shall provide financial resources to assist developing country Parties with respect to both mitigation and adaptation in continuation of their existing obligations under the convention" in Article 9 (UNFCCC, 2015: 13). The Paris Decision reaffirmed the USD 100 billion goal, which has been reached at the conference of parties (COP) in Copenhagen in 2009 (UNFCCC, 2015: 17).

However, USD 100 billion's annual target to address climate change is quite ambitious because the average transfer from developed countries to developing 
countries from 2015 and 2018 was the only USD 58.5 billion (Buchner et al., 2019: 24). Considering that most developed countries have not met their target, $0.7 \%$ of ODA/GNI, countries could understand both goals of development aid and climate finance are quite challenging at the current level. Also, developed countries have been required to acknowledge climate finance as a "new and additional" resources over the commitment of $0.7 \%$ because of the role that developed countries played in causing current and forthcoming climate change risks (Gupta, 2009: 210).

\section{3) Overview of climate finance and CRDF}

Climate finance has been one of the main issues under the United Nations Framework Convention on Climate Change (UNFCCC). As a milestone of climate finance negotiations, the establishment of the Green Climate Fund (GCF) as a financial mechanism under the UNFCCC was endorsed, and in 2009 developed countries agreed to mobilize USD 100 billion per year "new and additional" funds by 2020 to assist developing countries (Cui \& Huang, 2018: 173). Since 2010, the Standing Committee on Finance (SCF) under the UNFCCC has been tracking both public and private climate finance flows (UNFCCC, 2018: 9).

According to the 2018 biennial assessment by the SCF, climate finance, which is not only for developing countries but as a whole amount, flows increased by 17 percent in the period 2015-2016 compared to the period 2013-2014 (UNFCCC, 2018: 6). High-bound climate finance estimates increased from USD 584 billion in 2014 to USD 680 billion in 2015 and USD 681 billion in 2016 (UNFCCC, 2018: 6). The public climate finance includes the government budgets, finance from the development finance institutions (DFIs), and climate funds. The private climate finance consists of investment by corporate actors, households, and project developers, including private equity, venture capital, and infra funds (Oliver et al., 2018: 5). Also, the Climate Policy Initiative (CPI) report shows that private climate finance has continuously been more considerable than the public one since 2013 (Buchner et al., 2019: 3). Despite the smaller scale of public sources to private investment, public sources are still critical because it is possible to leverage private finance approximately with a ratio of 1:5 (World Economic Forum, 2013: 7). 
According to the OECD, CRDF includes parts from ODA, OOF, private grants, and private amounts reported by DAC and non-DAC members for developing countries (OECD, 2018: 2). The most substantial proportion of CRDF is from ODA, the public resource (See〈Figure 1〉). Although CRDF could not show all the efforts by the country to mobilize climate finance for developing countries, it would be inevitable to analyze the flow of climate finance at a country level.

\section{4) Korea's CRDF}

The data of Korea's CRDF consists mostly of grants and a debt instrument. These are concessional and developmental finance from the public sources, and all amounts would be counted as ODA1). Since 2013, although Korea's ODA has increased continuously, the CRDF has fluctuated without an increasing trend in terms of volume and proportion (See〈Table 1)).

This data suggests the Korean government did not have a road map or a specific plan to extend CRDF despite ODA's rise for the last years. Also, there was no particular allocation ratio between grants and debt instruments for CRDF at a planning stage by the government. In 2014, both the amount of CRDF, $\$ 144.80$ million, and the ratio of CRDF to ODA, 6.1\% are the lowest. There

〈Figure 1) Scope of CRDF between ODA, OOF, and Climate Finance

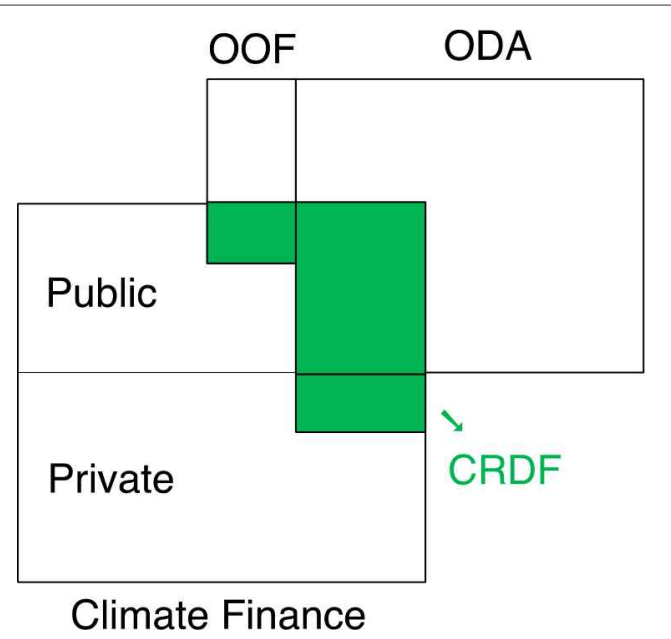

CRDF, Climate-Related Development Finance; ODA, Official Development Assistance; OOF, Other Official Flows.

1) In this paper, only concessional funds are considered as CRDF for comparison with other countries for years. 
〈Table 1〉 Korea's CRDF (2013-2018, current million \$)

\begin{tabular}{c|c|c|c|c|c|c}
\hline Year & 2013 & 2014 & 2015 & 2016 & 2017 & 2018 \\
\hline Grants & 142.24 & 134.80 & 176.45 & 185.19 & 227.17 & 286.57 \\
(\% of total) & $(46.6 \%)$ & $(93.1 \%)$ & $(48.0 \%)$ & $(51.3 \%)$ & $(56.4 \%)$ & $(82.3 \%)$ \\
\hline $\begin{array}{c}\text { Debt instruments } \\
\text { (\% of total) }\end{array}$ & 162.75 & 10 & 191.29 & 176.08 & 175.60 & 61.59 \\
\hline CRDF (Total) 2$)$ & $304.9 \%)$ & $(6.9 \%)$ & $(52.0 \%)$ & $(48.7 \%)$ & $(43.6 \%)$ & $(17.7 \%)$ \\
\hline ODA commitment3) & $2,238.2$ & $2,378.33$ & 367.74 & 361.27 & 402.77 & 348.16 \\
\hline CRDF/ODA (\%) & 13.6 & 6.1 & 15.9 & 14.7 & 16.5 & 12.2 \\
\hline
\end{tabular}

Source: Climate Change: OECD DAC External Development Finance Statistics, reorganized by author.

CRDF, Climate-Related Development Finance; ODA, Official Development Assistance.

might be some data collection issues because of the massive amount of non-concessional funds, which is not consistent with other years' data.

\section{Significance of the Problem}

Without contributing to climate finance for developing countries, Korea can result in the "naming and shaming" situation in the global community as a massive $\mathrm{CO}_{2}$ emitter. Korea is the $8^{\text {th }}$ largest $\mathrm{CO}_{2}$ emitter in the world and the $4^{\text {th }}$ largest among OECD DAC countries in 2018 (Union of Concerned Scientists, 2020). In terms of per capita emission, Korea is the $6^{\text {th }}$ heaviest globally and the $4^{\text {th }}$ heaviest among OECD DAC countries (Union of Concerned Scientists, 2020). As the socio-ecological model shows the relationship around climate finance issues, the challenge of addressing climate change is complicated by the variety of stakeholders (See〈Appendix 1〉). Korea has been ranked quite poorly in many environment, and development indicators, for instance, as $57^{\text {th }}$ out of 60 countries in climate change performance index (Germanwatch, 2018); $27^{\text {th }}$ out of 27 countries in the commitment to development index 2018 (Center for Global Development, 2018); and "highly insufficient group," in which the

2) Non-concessional funds, $\$ 155$ million in 2014 and $\$ 18$ million in 2015 , are excluded from the total.

3) For consistency with CRDF, the data of ODA is used in commitment level. 
government's policy could make global warming between $3^{\circ} \mathrm{C}$ and $4^{\circ} \mathrm{C}$, not consistent with Paris Agreement's goal below 2 (Climate Action Tracker, 2019). It means that Korea has a more significant responsibility not only to make an effort to reduce $\mathrm{CO}_{2}$ emissions but also to assist developing countries in addressing the hazards of climate change. The burden-sharing framework for climate finance, which is associated with historical responsibility, ability to pay, and equity, suggested the required level for Korea between $1.6 \%$ and $4.5 \%$ of the total. Still, Korea's contribution to the GCF has been only $1 \%$ of the total resource (Moon, 2016: 228).

The Korean government needs more cooperation with developing countries to meet its goal of NDC by 2030. The greenhouse gas (GHG) Mitigation Roadmap by the 2030 year set the goal to reduce emission in total $37 \%$ compared to business as usual (BAU), 32.5\% from the domestic industries and the rest 4.5\% from the forest absorption and reduction in other countries (Government of Korea, 2018: 5). According to Article 6 of the Paris Agreement, "some Parties choose to pursue voluntary cooperation in the implementation of their NDC" (UNFCCC, 2015: 7). To "hold the increase in the global average temperature to well below $2^{\circ} \mathrm{C}$ above pre-industrial levels", every country should use various approaches and cooperate. Korea also needs to meet not only its goal of NDC but also global target through cooperation with other countries and should contribute more climate finance and technology towards the efforts of developing countries. However, the Korean government thus far has not allocated sufficient budget resources and did not adopt appropriate cooperation initiatives in developing countries. Therefore, the Korean government needs a strategy to increase climate finance from both public and private resources by endorsing effective policy measures.

\section{Prior Efforts and Their Assessment}

The Korean government has used CRDF as a primary public source to address climate change issues in developing countries. CRDF is disbursed by the Ministries and governmental aid agencies, such as the Ministry of Foreign Affairs (MOFA), Ministry of Economy and Finance (MOEF), Korea International Cooperation 
Agency (KOICA), Export-Import Bank of Korea (Korea Eximbank), and other agencies. KOICA implemented 338 grant projects with $\$ 76$ million, and Korea Eximbank managed $\$ 61$ million for a project using debt instruments in 2018 (See 〈Table 2)). While KOICA worked on $70.9 \%$ of total projects, with only $21.7 \%$ of the total budget, other agencies implemented $24.7 \%$ of entire projects, with $45.4 \%$ of the total budget.

Within this structure, the Korean government sometimes initiates special pledges on climate change. For example, the Korean government designated KOICA as an operating agency for the East Asia Climate Partnership (EACP) from 2008 to 2012, spending USD 200 million to deal with climate issues in developing countries (Office for Government Policy Coordination, 2013). After that, KOICA announced a plan to support climate change mitigation and adaptation with USD 100 million from 2021 to 2025 in the 1st KOICA Climate Action Partnership Forum (Wang, 2019). Furthermore, the Republic of Korea president, Moon Jae-in, pledged that Korea doubles its contributions to the GCF and hosts the second P4G Summit in 2020 (The president of Korea, 2019). P4G is "a network of global leaders and innovators seeking breakthrough solutions for green economic growth"; it "accelerates, funds and recognizes innovative public-private partnerships" (P4G, 2019). However, such one-time commitment is not a sustainable scheme to attract private investment for climate issues in developing countries. Although the Korean government wants to develop cooperation with the private sector through $\mathrm{P} 4 \mathrm{G}$, the scale of support is

\section{〈Table 2〉 Korea's CRDF by implementing agency in 2018 (current million \$)}

\begin{tabular}{c|c|c|c|c|c|c}
\hline Agency & KOICA & $\begin{array}{c}\text { Korea } \\
\text { Eximbank }\end{array}$ & MOFA & MOEF & $\begin{array}{c}\text { Other } \\
\text { agencies }\end{array}$ & Total \\
\hline $\begin{array}{c}\text { Number of } \\
\text { projects }\end{array}$ & $\begin{array}{c}338 \\
(70.9 \%)\end{array}$ & $\begin{array}{c}1 \\
(0.2 \%)\end{array}$ & $\begin{array}{c}6 \\
(1.3 \%)\end{array}$ & $\begin{array}{c}14 \\
(2.9 \%)\end{array}$ & $\begin{array}{c}118 \\
(24.7 \%)\end{array}$ & $\begin{array}{c}477 \\
(100 \%)\end{array}$ \\
\hline Amount & $\begin{array}{c}76 \\
(21.7 \%)\end{array}$ & $\begin{array}{c}61 \\
(17.7 \%)\end{array}$ & $\begin{array}{c}14 \\
(4.1 \%)\end{array}$ & $\begin{array}{c}39 \\
(11.1 \%)\end{array}$ & $\begin{array}{c}158 \\
(45.4 \%)\end{array}$ & $\begin{array}{c}348 \\
(100 \%)\end{array}$ \\
\hline
\end{tabular}

Source: Climate Change: OECD DAC External Development Finance Statistics, reorganized by author.

CRDF, Climate-Related Development Finance; KOICA, Korea International Cooperation Agency; MOFA, Ministry of Foreign Affairs; MOEF, Ministry of Economy and Finance; OECD, Organization for Economic Cooperation and Development. 
relatively small because primary beneficiaries of the program are early-stage companies.

On top of that, the CRDF could be increased through other public climate financial resources. As 〈Figure 1〉 shows, incremental public climate finance through emission trading schemes (ETS), green bonds, or a carbon tax would bring more resources for cooperation with developing countries. The Korean government has issued six green bonds of $\$ 2.05$ billion by four issuers, but this amount is still small compared to global needs (Climate Bond Initiatives, 2018: 4). Korea Eximbank was the first issuer to come to market in 2013 and the only repeat issuer to date, accounting for $46 \%$ of total issuance (Climate Bond Initiatives, 2018: 5). Since 2015, the Korean government has been operating ETS to reduce GHG emissions. However, the Korean government did not have the experience to use financial resources from the ETS because the allowance was distributed free of charge to the participants in phase 1 from 2015 to 2017 (Asian Development Bank, 2018: 15). On the other hand, because 3\% and 10\% of the allowances are auctioned, respectively, in Phase 2 (2018-2020) and Phase 3 (2021-2025) (IETA, 2016: 4), there would be an opportunity to use this revenue for developing countries.

\section{PROBLEM ANALYSIS}

There are three main reasons why Korea's climate finance is insufficient: shortage of ODA and its fragmented implementation, lack of other public climate finance, and low level of public-private partnerships (See 〈Appendix 2〉). While there are various factors that contribute to the problem, its leading root causes are the following: bureaucratic failure, diffusion of authority, information asymmetry, and the problem of uncertainty.

\section{Bureaucratic Failure Makes Fragmented CRDF Implementation}

Korea has been the $8^{\text {th }}$ largest country by GNI among 29 countries of the OECD DAC in 2018 (The World Bank, 2019). However, ODA in 2018 on a grant 
equivalent basis is $15^{\text {th }}$ as of USD 2,351 million, and the ODA per GNI is $0.15 \%$, ranked $24^{\text {th }}$ (OECD, 2019b: 6). Although Korea's ODA has increased gradually since 2010 (OECD, 2020b), it is substantially lower than its economic rank. While the Korean government initially set up its ODA/GNI goal of $0.25 \%$ by 2015 (OECD, 2018: 351), the target was not achieved and was changed to $0.20 \%$ by 2020 (MOFA, 2015). However, it is expected that the second goal would not be met by 2020 as well. The Korean government usually prioritizes domestic issues over foreign policy concerns, and the ODA budget is easily sacrificed to urgent domestic needs, which are more politically expedient for the administration. This insufficient ODA could limit CRDF because a public source of CRDF comes almost from ODA. In 2018, Korea's CRDF, USD 348 million, and CRDF per ODA, $12.2 \%$, was lower than the average of DAC countries, respectively, USD 1,183 million and 22.2\% (See〈Table 3〉).

On the other hand, Japan, Germany, and France are top donors of CRDF. For comparison, the three countries would be good examples because they are top donors and have similar ODA structures to Korea. Korea and the three countries are the top five countries for high loan shares in gross bilateral ODA in DAC countries (See〈Figure 2〉).

Also, in terms of $\mathrm{CO}_{2}$ emissions, Korea was the fourth largest country in DAC members right after Japan $\left(2^{\text {nd }}\right)$ and Germany $\left(3^{\text {rd }}\right)$ and emitted more than France did in 2018 (Union of Concerned Scientists, 2020). Korea's responsibility for burden-sharing in climate change should not be much less than these countries. However, Korea's CRDF, \$348 million, is considerably lower than that of these countries. A low proportion of debt instruments, 17.7\%, could limit Korea's CRDF, compared to Japan, 91.2\%, Germany 50.0\%, and France 65.8\% (See 〈Table $4\rangle$ ). Compared to the proportion of more than $40 \%$ loans in the entire ODA, the Korean government has committed climate-related projects with loans, only 17.7\%. Still, Japan, Germany, and France have allocated more loans for climate-related projects.

In addition to the limited scale of CRDF, the problem is rooted in fragmented planning and implementation as a bureaucratic failure. First, Korea's development agencies spent $\mathrm{CRDF}$ at the lowest proportion, 39.4\%, compared to Japan, 91.9\%, Germany 88.7\%, France 84.3\%, respectively (See〈Table 5〉). It 
〈Table 3〉 DAC countries' CRDF and CRDF/ODA in 2018 (current \$)

\begin{tabular}{|c|c|c|c|c|}
\hline & Country & CRDF (mil.\$) & CRDF/ODA & CRDF/ODA (rank) \\
\hline 1 & Japan & 10,673 & 0.553 & 1 \\
\hline 2 & Germany & 8,841 & 0.350 & 4 \\
\hline 3 & United Kingdom & 3,112 & 0.389 & 3 \\
\hline 4 & France & 2,349 & 0.248 & 12 \\
\hline 5 & Sweden & 1,683 & 0.403 & 2 \\
\hline 6 & United States & 1,426 & 0.046 & 28 \\
\hline 7 & Netherlands & 1,080 & 0.292 & 7 \\
\hline 8 & Canada & 808 & 0.243 & 13 \\
\hline 9 & Norway & 804 & 0.201 & 16 \\
\hline 10 & Switzerland & 504 & 0.201 & 17 \\
\hline 11 & Australia & 467 & 0.183 & 20 \\
\hline 12 & Italy & 439 & 0.188 & 19 \\
\hline 13 & Denmark & 387 & 0.234 & 14 \\
\hline 14 & Spain & 367 & 0.304 & 6 \\
\hline 15 & Belgium & 360 & 0.307 & 5 \\
\hline 16 & Korea & 348 & 0.122 & 22 \\
\hline 17 & Finland & 159 & 0.227 & 15 \\
\hline 18 & Austria & 142 & 0.279 & 9 \\
\hline 19 & Ireland & 90 & 0.170 & 21 \\
\hline 20 & New Zealand & 84 & 0.201 & 18 \\
\hline 21 & Poland & 77 & 0.288 & 8 \\
\hline 22 & Luxembourg & 36 & 0.102 & 24 \\
\hline 23 & Portugal & 15 & 0.093 & 25 \\
\hline 24 & Iceland & 11 & 0.268 & 11 \\
\hline 25 & Czech Republic & 11 & 0.106 & 23 \\
\hline 26 & Slovenia & 10 & 0.276 & 10 \\
\hline 27 & Greece & 6 & 0.085 & 26 \\
\hline 28 & Hungary & 3 & 0.022 & 29 \\
\hline \multirow[t]{2}{*}{29} & Slovak Republic & 2 & 0.061 & 27 \\
\hline & Average & 1,183 & 0.222 & \\
\hline
\end{tabular}

Source: Climate Change: OECD DAC External Development Finance Statistics, reorganized by author.

DAC, Development Assistance Committee; CRDF, Climate-Related Development Finance; ODA, Official Development Assistance; OECD, Organization for Economic Cooperation and Development. 
〈Figure 2〉 Share of loans in gross bilateral ODA for loan giving DAC countries (2018)

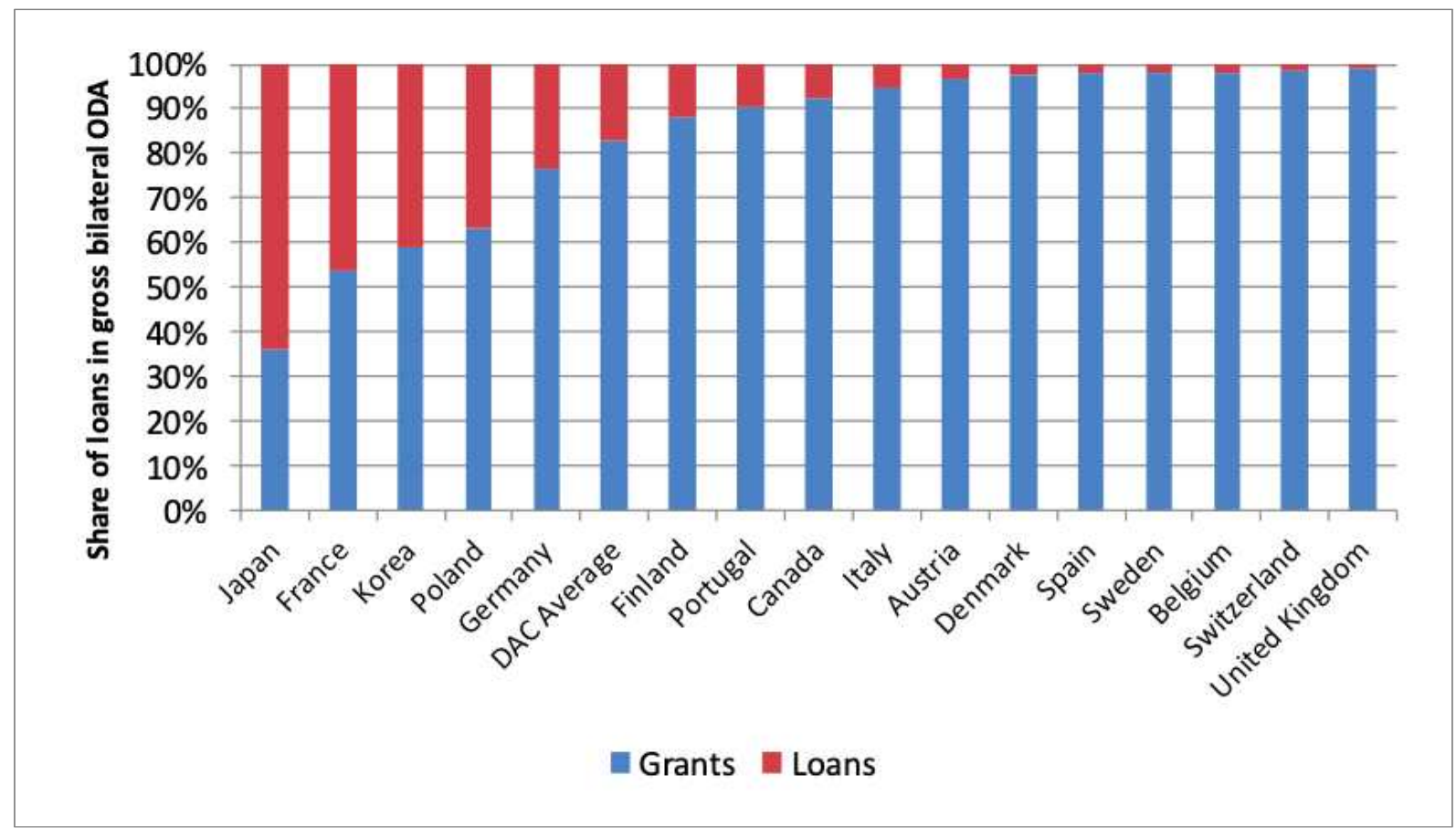

Source: OECD (2019), ODA 2018 detailed summary.

ODA, Official Development Assistance; OECD, Organization for Economic Cooperation and Development.

〈Table 4〉 Comparison of CRDF4) in 2018 (Korea, Japan, Germany, France)

\begin{tabular}{c|c|c|c|c}
\hline & Korea & Japan & Germany & France \\
\cline { 2 - 5 } & $\$$ mil. (\%) & $\$$ mil. (\%) & $\$$ mil. (\%) & $\$$ mil. (\%) \\
\hline \multirow{2}{*}{ Grants } & 287 & 944 & 4,318 & 702 \\
& $(82.3 \%)$ & $(8.8 \%)$ & $(48.8 \%)$ & $(29.9 \%)$ \\
\hline \multirow{2}{*}{ Debt instruments } & 61 & 9,729 & 4,421 & 1,546 \\
& $(17.7 \%)$ & $(91.2 \%)$ & $(50.0 \%)$ & $(65.8 \%)$ \\
\hline \multirow{2}{*}{ Equity\& shares } & - & - & 102 & 101 \\
\hline \multirow{2}{*}{ CRDF (total) } & 348 & 10,673 & $(1.2 \%)$ & $(4.3 \%)$ \\
\hline ODA commitment & $(100 \%)$ & $(100 \%)$ & $(100 \%)$ & $(100 \%)$ \\
\hline CRDF/ODA & 2,850 & 19,287 & 25,248 & 9,466 \\
\hline
\end{tabular}

Source: Climate Change: OECD DAC External Development Finance Statistics, reorganized by author.

CRDF, Climate-Related Development Finance; ODA, Official Development Assistance; OECD, Organization for Economic Cooperation and Development. 
〈Table 5〉 Comparison of CRDF by agency in 2018 (Korea, Japan, Germany, France)

\begin{tabular}{c|c|c|c|c|c|c|c|c}
\hline \multirow{2}{*}{} & \multicolumn{2}{|c|}{ Korea } & \multicolumn{2}{c|}{ Japan } & \multicolumn{2}{c|}{ Germany } & \multicolumn{2}{c}{ France } \\
\cline { 2 - 9 } & $\begin{array}{c}\text { No. } \\
(\%)\end{array}$ & $\begin{array}{c}\$ \text { mil. } \\
(\%)\end{array}$ & $\begin{array}{c}\text { No. } \\
(\%)\end{array}$ & $\begin{array}{c}\$ \text { mil. } \\
(\%)\end{array}$ & $\begin{array}{c}\text { No. } \\
(\%)\end{array}$ & $\begin{array}{c}\$ \text { mil. } \\
(\%)\end{array}$ & $\begin{array}{c}\text { No. } \\
(\%)\end{array}$ & $\begin{array}{c}\text { \$ mil. } \\
(\%)\end{array}$ \\
\hline $\begin{array}{c}\text { Development } \\
\text { agencies5) }\end{array}$ & $\begin{array}{c}339 \\
(71.1 \%)\end{array}$ & $\begin{array}{c}137 \\
(39.4 \%)\end{array}$ & $\begin{array}{c}733 \\
(87.5 \%)\end{array}$ & $\begin{array}{c}9,813 \\
(91.9 \%)\end{array}$ & $\begin{array}{c}848 \\
(59.1 \%)\end{array}$ & $\begin{array}{c}7,845 \\
(88.7 \%)\end{array}$ & $\begin{array}{c}79 \\
(8.8 \%)\end{array}$ & $\begin{array}{c}1,980 \\
(84.3 \%)\end{array}$ \\
\hline $\begin{array}{c}\text { Other } \\
\text { agencies }\end{array}$ & 138 & 211 & 105 & 860 & 586 & 996 & 823 & 369 \\
\hline \multirow{2}{*}{ Total } & $(28.9 \%)$ & $(60.6 \%)$ & $(12.5 \%)$ & $(8.1 \%)$ & $(40.9 \%)$ & $(11.3 \%)$ & $(91.2 \%)$ & $(15.7 \%)$ \\
\hline
\end{tabular}

Source: Climate Change: OECD DAC External Development Finance Statistics, reorganized by author.

CRDF, Climate-Related Development Finance; OECD, Organization for Economic Cooperation and Development.

means that more of Korea's non-developmental agencies were involved in spending CRDF. Although France's other agencies managed $91.2 \%$ of the total projects, the amount is only $15.7 \%$. However, Korea's other agencies implemented $28.9 \%$ of the entire projects, with $60.6 \%$ of the total budget. It suggests that development agencies do not mainly channel Korea's CRDF spending.

In Korea's ODA planning and budgeting system, bottom-up planning would cause a low and unstable rate of CRDF per ODA. Korea's CRDF from 2013 to 2018 suggested that there was no consistent and overall plan to deal with climate change issues for developing countries (See 〈Table 1〉). MOFA and MOEF are in charge of coordinating grants and concessional loans, respectively. However, the specific projects and programs are usually organized from scratch by the other 41 implementing ministries or governmental agencies. Although the Committee for International Development Cooperation (CIDC) under the Prime Minister tries to control the programs from 40 organizations, this coordination is less efficient than that one or two leading development agencies plan and

4) For comparison, a part of CRDF, which is not concessional or not primarily developmental, is excluded, but only France has six non-concessional projects with 415 million USD.

5) Each country's development agencies: (Korea) KOICA, Korea Eximbank, (Japan) Japan International Cooperation Agency (JICA), (Germany) Kreditanstalt für Wiederaufbau (KfW), Bundesministerium für wirtschaftliche Zusammenarbeit und Entwicklung (BMZ), (France) Agence Française de Développement (AfD) - French Development Agency, Proparco. 
implement most CRDF projects as Japan, Germany, and France do. Moreover, due to climate-related projects' identification without a top-down and comprehensive strategy, Korea's CRDF per ODA ratio fluctuates every year. It seems that the CIDC cannot control this fluctuation under the current fragmented system.

\section{Diffusion of Authority Limits Climate Financing}

Even though ODA is the central public resource to support developing countries, the other climate-related public resources are necessary to expand assistance to developing countries. Also, Korea needs more public funds or budget, USD 24 bn, to meet NDC of GHG emission by 2030 (Jin \& Kim, 2016: 68). Low birth rate and aging population will lower the economic growth rate, and the sources of public finance will be shrinking from the reduction of population in the long term in Korea (Jin \& Kim, 2017: 153).

For leveraging more private climate finance under the various conditions of uncertainty, public climate finance should be managed by an integrated framework. However, the Korean government has separate channels for implementing climate change policy and energy policies. First, for climate change policy, the Office for Government Policy Coordination under the Prime Minister provides overall coordination, while the Ministry of Environment (MOE), the Ministry of Trade, Industry and Energy (MOTIE), the Ministry of Land, Infrastructure, and Transport (MOLIT), the Ministry of Agriculture, Food and Rural Affairs (MOAFR) are responsible for managing the reduction of GHG emissions in each sector. For Korea Emissions Trading Scheme (KETS), the MOEF and the MOE are the coordinating ministries, and the MOTIE, MOLIT, MOAFR, and other ministries managed issues from each sector (Greenhouse Gas Inventory and Research Center, 2019: 18). Besides, for energy policy, the MOTIE manages the establishment of a national energy plan and other detailed action plans.

Under the separate coordination structure, relevant budgets related to climate change and energy are allocated through different decision-making channels. Also, Korea's policy integration of public climate finance is low in terms of 
evaluation criteria such as inclusion, consistency, weight, reporting, resources, and deliberation (Jin \& Kim, 2016: 55). The governance structure needs to be improved, and making an integrated and reliable channel would help to deal with climate change policy and energy policy comprehensively (Jin \& Kim, 2016: 72).

\section{Asymmetry Information and Uncertainty Hinder Private Investment}

For foreign direct investment (FDI) to developing countries, Korea was the 7th largest country out of 29 OECD DAC countries in terms of the total amount from 2010 to 2017 (OECD, 2019). This rank is high, compared to the volume of ODA (15th) and ODA per GNI (26th) in 2017. However, this potential private investment is not linked to climate change projects because of poor risk management and limited incentives provided for private actors by public finance.

Also, the Korean government could not control non-financial risks related to information asymmetry, lack of experts, and inconsistent policy and planning (KPMG, 2018: 22). Many citizens have poor understanding about climate finance and environment industries, and poor analysis and evaluation of the relevant projects cannot attract private investment. The government's response to climate change is one of the primary administration's plans, but separate policies in each ministry deteriorate the whole government's consistency and integrity (KPMG, 2018: 22). This policy uncertainty and lack of information leads to immoderate risk aversion by investors towards renewable energies and energy-saving technologies (G20 Green Finance Study Group, 2016: 11).

In the climate change sector, there is a discrepancy in demand and supply between investors and investees, and this gap is a market failure due to the lack of public finance safety net (Jin \& Kim, 2016: 56). Investors want to get a high return because climate-related projects are risky, but business operators can make lower interest than investor's expectations (Jin \& Kim, 2016: 44). Although business operations in low carbon technology and renewable energy require longer maturity of finance with a high upfront cost, private investors want lesser periods of maturity (Jin \& Kim, 2016: 58). Also, climate-related projects would be implemented with other risk factors such as participation of small and medium-sized companies, low credit of developing countries, and an unmatured 
level of technology (KPMG, 2018: 21). These factors could hinder private investment in climate change projects in developing countries. If the Korean government wants to mobilize more resources from private sectors, the government needs to hedge them against risks with public sources.

\section{STRATEGY ANALYSIS}

\section{Relevant Experience from Other Countries}

As problem analysis demonstrates, the Korean government needs to intervene for mobilizing more climate finance in three domains: increasing ODA and assigning more CRDF in ODA; raising other public climate financial sources; and leveraging more private climate investment (See〈Figure 3〉). These sources are all connected and affect each other.

The Korean government could benefit from lessons from Japan, Germany, and France because the three countries are top donors of CRDF and have a relatively similar ODA structure using a high proportion of loans like Korea. Also, the three countries' development agencies disburse more CRDF than total ODA in terms of ratio (See 〈Table 6)).

It suggests the Korean government could increase CRDF by allocating more budget to development agencies and using debt instruments even though the entire ODA's disbursement is not quite centralized. Beyond the high proportion of development agencies' CRDF spending, Japan, Germany, and France mobilize public climate finance from various policy measures such as carbon tax, Joint

〈Figure 3〉 Financial sources of CRDF

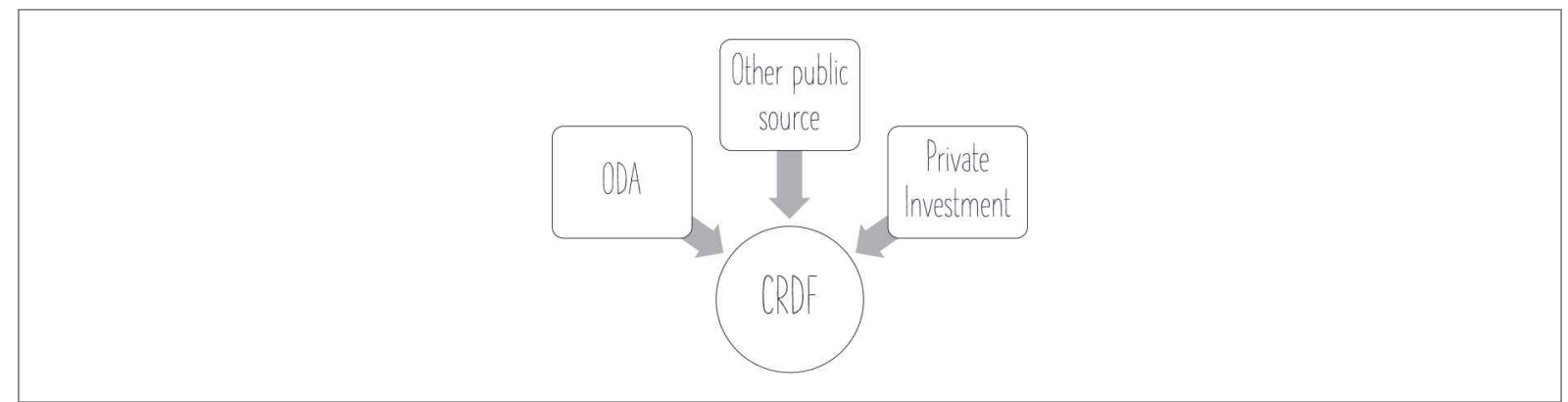

CRDF, Climate-Related Development Finance. 
〈Table 6〉 Comparison of Development Agencies' disbursement proportion (\%) of ODA and CRDF in 2018 (Korea, Japan, Germany, France)

\begin{tabular}{c|c|c|c|c}
\hline & Korea & Japan & Germany & France \\
\hline Total ODA & $52.7 \%$ & $64.5 \%$ & $64.7 \%$ & $48.2 \%$ \\
\hline CRDF & $39.4 \%$ & $91.9 \%$ & $88.7 \%$ & $84.3 \%$ \\
\hline Gap (CRDF-ODA) & $-13.3 \% p$ & $27.4 \% p$ & $24.0 \% p$ & $36.1 \% p$ \\
\hline
\end{tabular}

Source: OECD (2020), Development Cooperation Profiles 2020, External Development Finance Statistics.

ODA, Official Development Assistance; CRDF, Climate-Related Development Finance; OECD, Organization for Economic Cooperation and Development.

Crediting Mechanism (JCM), ETS, and green bond. The Korean government could adopt some policy options to increase climate finance from the three countries' experiences.

\section{1) Japan}

After the adoption of the "Basic Act on Global Warming Countermeasures," the Japanese government levied the global warming tax in addition to petroleum and coal tax on fossil-fuel consumption, including electricity generation (KPMG, 2018: 58). The Japanese government uses the tax revenue not only for a domestic purpose but also for the cooperation projects, JCM in developing countries. The JCM is a system for cooperation with developing countries to reduce GHG emissions, in which the result of the reduction is assessed as contribution by both partner countries and Japan (Ministry of Foreign Affairs of Japan, 2018). The main domains of JCM are renewable energy, energy reduction, waste management, and transport. Since Prime Minister Abe's announcement of this initiative at the COP 21, the Japanese government has signed JCM with 17 countries, including those in Asia, Africa, Small Island Developing States (SIDSs), Latin America, and the Middle East (Ministry of Foreign Affairs of Japan, 2018). The Ministry of the Environment of Japan (MOEJ) and Japan International Cooperation Agency (JICA) are the primary implementers for the JCM projects.

\section{2) Germany}

Germany has various programs to mobilize climate finance. Since 2008, the 
International Climate Initiative (IKI) of the Federal Ministry for the Environment, Nature Conservation and Nuclear Safety (BMU) has been financing climate and biodiversity projects in developing and newly industrializing countries, as well as in countries in transition (Federal Ministry for the Environment, Nature Conservation and Nuclear Safety, 2019). In the early years of the program, its financial resources came from the revenues of auctioning allowances under the ETS. For ensuring financial continuity, further funds were made available through the Special Energy and Climate Fund (Federal Ministry for the Environment, Nature Conservation and Nuclear Safety, 2019). The Initiative emphasizes clearly on climate change mitigation and adaption, as well as the protection of biological diversity. The uniqueness of the program is that the German government uses revenues from ETS actively for cooperation with developing countries.

\section{3) France}

France issued a green bond of 9.7 billion euros, which was the largest program of that kind in Europe in 2017. Since the adoption of the "Act of Energy Transition for Green Growth" in 2015, the French government has issued a green bond to mobilize funds for implementing policies related to climate change and the environment. Also, after the Paris Agreement in 2015, French development agency, AFD, has set an ambitious goal - an activity that's "100\% Paris Agreement" (AFD, 2019). As a central development agency of the French government, AFD committed 4.8 billion euros to the climate in 2018, and $50 \%$ of the AFD Group's activity had co-benefits for the climate (AFD, 2019). Moreover, AFD managed climate bonds for financing 128 projects with 3.5 billion euro in 2018 (AFD, 2018: 7). Renewable energy, energy efficiency, and transport were the main sectors, more than $80 \%$ of the asset portfolio (AFD, 2018: 7).

\section{Description of Alternative Options}

\section{1) Design of alternative options}

From the problem analysis, root causes seem types of market failure (MF), 
limitation of the competitive framework (LCF), and government failure (GF). Information asymmetry is a kind of MF, and uncertainty problem is a type of LCF. Also, bureaucratic failure and diffusion of authority are representative GF. Regarding every type of problem, there are some generic policy solutions in the view of policy analysis. Despite more generic policies available in each category, the most appropriate potential policies are setting rules and making insurance and cushions (See 〈Table 7〉).

As a result, four alternative options are composed of a combination of generic policies. Alternative 1 is status-quo with no structural change in the government. However, the current system needs to be used actively to fix the identified types of MF and LCF. Alternative 2 suggests integrating the ODA implementation system within the government based on the condition of Alternative 1 because the ODA system is vital as a main delivery channel of public climate finance to developing countries. Alternative 3 focuses on changing the structure of the Korean administration related to climate policy (CP), including elements of Alternative 1. This approach makes the government's decision-making system more efficient and predictable. Lastly, Alternative 4 is a comprehensive combination of all elements of Alternatives (See〈Figure 4〉).

\section{2) Alternative 1: Upgraded Status-Quo}

Alternative 1 focuses on solving information asymmetry and uncertainty

\section{〈Table 7〉 Potential generic policies for improving Korea's climate finance}

\begin{tabular}{c|c|c|c}
\hline \multirow{2}{*}{ Problems } & Market failure (MF) & $\begin{array}{c}\text { Limitation of competitive } \\
\text { framework (LCF) }\end{array}$ & Government failure (GF) \\
\cline { 2 - 4 } & $\begin{array}{c}\text { Information } \\
\text { asymmetry }\end{array}$ & $\begin{array}{c}\text { Problem of } \\
\text { uncertainty }\end{array}$ & $\begin{array}{c}\text { Bureaucratic failure and } \\
\text { diffusion of authority }\end{array}$ \\
\hline \multirow{2}{*}{$\begin{array}{c}\text { Generic } \\
\text { policy } \\
\text { solutions }\end{array}$} & $\begin{array}{c}\text { Rules: Setting a new law or regulation for } \\
\text { private investors to share information and } \\
\text { facilitate their investment } \\
\text { - Insurance and cushions: Applying new financial } \\
\text { instruments to lower private investors' risks }\end{array}$ & $\begin{array}{l}\text { Rules: Setting a new law to } \\
\text { integrate ODA implemen- } \\
\text { tation }\end{array}$ \\
\hline & & $\begin{array}{l}\text { Rules: Setting a new law to } \\
\text { change governance in climate } \\
\text { change policy }\end{array}$ \\
\hline
\end{tabular}

Source: (Weimer \& Vining, 2017), reorganized by author.

ODA, Official Development Assistance. 


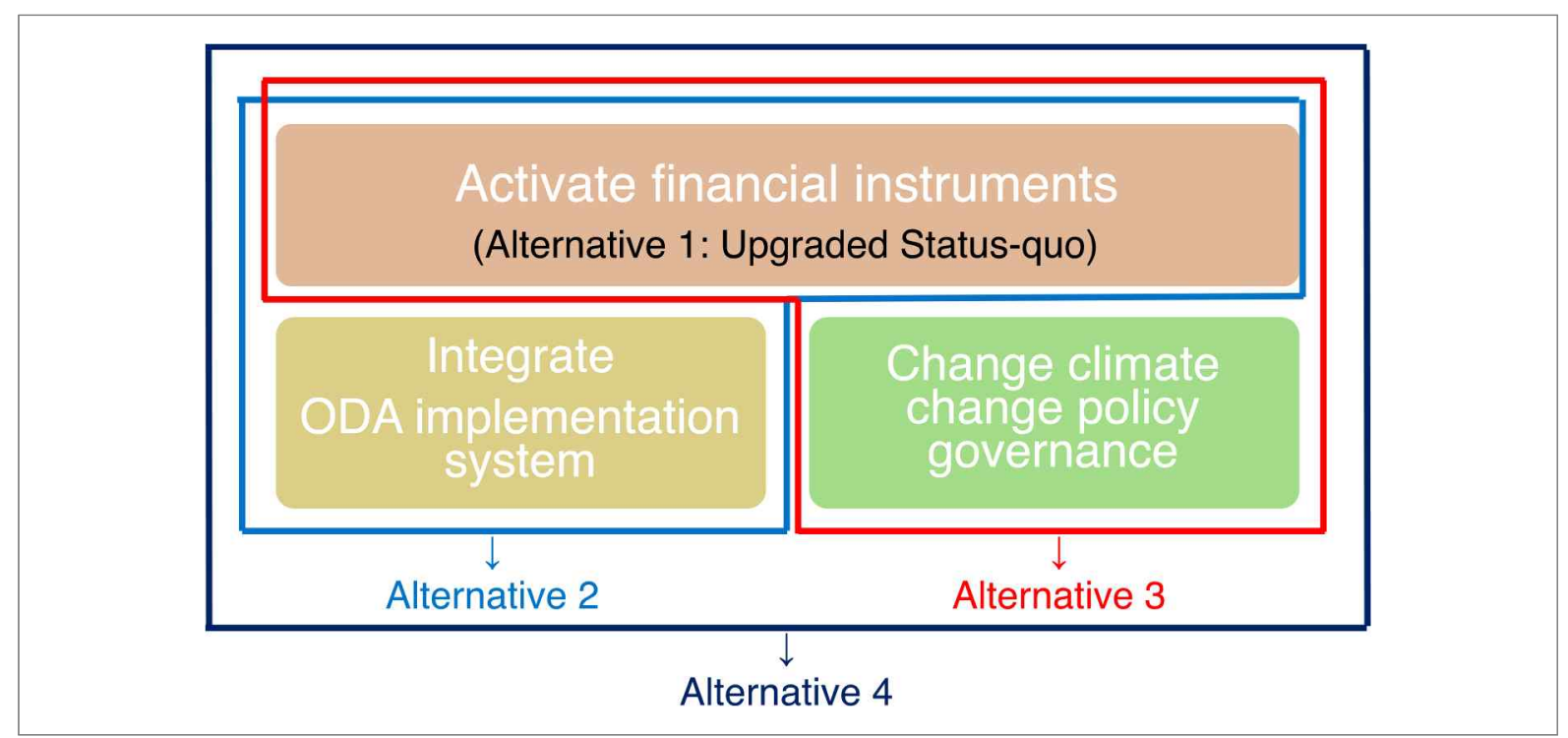

ODA, Official Development Assistance.

problems of the private sector without a structural change of the government. The Korean government uses the current system related to climate finance but applies some modifications and improvements to each policy measure. That is why Alternative 1 is called as upgraded status-quo. Korea's CRDF spending is decentralized and more agencies are involved in, compared to Japan, Germany, and France. However, although it is not an ideal model, the Korean government has a coordination process between governmental bodies (Office for Government Policy Coordination, 2020). KOICA and Korea Eximbank implement more ODA programs, respectively $22.7 \%$ and $30.0 \%$ of the total, than other nondevelopmental agencies (OECD, 2020b). If the Korean government allocates more ratio of CRDF to KOICA and Korea Eximbank than that of the entire ODA as Japan, Germany, and France do. In that case, Korea could leverage more private climate finance with public sources.

Since 2018, KOICA has applied to be an accredited entity by GCF (Wang, 2018). Japan, Germany, and France already have GCF's accredited entities such as JICA, GIZ, KfW, and AFD. If getting the accreditation, KOICA could have more chances to work closely with various stakeholders related to climate change issues. It means that KOICA could have more information to share with private partners to solve information asymmetry for private investors. Moreover, 
if the Korean government wants to utilize the KOICA's accreditation fully, KOICA needs more function to attract private investment for its program. A separate KOICA's climate change fund could play a significant role in cooperating with private investors, supporting public-private partnership projects with KOICA's grants (Kim \& Lee, 2019: 125). This type of guarantee for private investment would work as insurance and cushions to reduce the uncertainty problem.

On top of that, Korea Eximbank was not able to be an accredited entity by GCF due to one of the organization's characteristics, which is directly supporting Korean companies' business (Byun, 2016). However, as a bank, Korea Eximbank has attractive measures to work with private investors. Korea Eximbank has been one of the institutions to issue green bonds since 2013 (Climate Bond Initiatives, 2018: 5) and a public financial institution for market stability and invigoration in KETS. Also, the Korean government has reviewed how to increase Korea's contribution to international development by using blended finance since 2016 (Korean Ministry of Economy and Finance, 2016). Korea already reviewed or adopted some policy measures to increase cooperation with private partners like Japan, Germany, and France, but the Korean government did not fully utilize them. So, if the Korean government improves some financial instruments to enhance the partnership, it will be an upgraded status-quo as Alternative 1.

\section{3) Alternative 2: Integrating the ODA implementation system}

A leading financial resource of CRDF is the government budget considered as ODA. Public climate finance is commonly set up for domestic use about climate issues, but if the government uses a part of a fund to support developing countries, the fund will be calculated as ODA. So, in order to improve Korea's climate finance for developing countries, ODA implementation system should be efficient. Also, the amount of ODA program budget is a critical part of having effectiveness in developing countries. If the budget is quite small, the amount could limit the effectiveness or affect the quality of the program. The efficient ODA implementation system does not guarantee to increase the program's budget itself, but the government could choose and focus on the programs with 
a considerable amount based on the efficient system. Moreover, the fewer government agencies are involved in ODA implementation, the more effective is its monitoring and evaluation.

The concern about fragmentation of Korea's ODA has been raised since the beginning of the 2000s when ODA has surged (Prime Minister of Korea, 2018: 1). Under the CIDC, chaired by the Prime Minister, MOEF and MOFA are coordinating ministries for each concessional loan and grants (Office for Government Policy Coordination, 2020). Besides, there are more than 40 implementing agencies for grants, and transaction cost is high to coordinate them and make the consistency of the annual ODA plan. Despite various problem analyses and researches, there was no real progress in alleviating the fragmentation of the ODA system.

Also, Japan, Germany, and France do not have a highly centralized ODA implementation system like Korea (OECD, 2020a). However, the Japanese ODA system is more centralized than that of others after establishing a new JICA, merged between JICA and the Overseas Economic Cooperation Fund (OECF), in 2008 (JICA, 2020). The current JICA has a more efficient system to execute projects with private partners because it has various financial schemes, including grants, loans, other types of financial instruments. Nevertheless, the reason for JICA's merge was not for better performance in spending ODA. There was a political incentive of the Koizumi administration to reorganize public financial institutions after the privatization of Japan Post (Han et al., 2015: 212). Therefore, integrating the ODA implementation system would be necessary for efficiency and effectiveness, but it is not easy to be accessible due to other governmental bodies' objections. Because the governmental organizations do not want to lose their works and budgets, the ODA system's integration is politically complicated.

\section{4) Alternative 3: Changing governance in $\mathrm{CP}$}

To increase climate finance consistently, one needs to change climate governance because it affects the decision-making process for mobilizing public climate finance and participation of the private stakeholders. Although climate change issues and finance are closely related to the energy sector, different 
Ministries are responsible for each issue (Jin \& Kim, 2016: 71-72). For the GHG emissions mitigation policy, a central coordinating Ministry is MOE. MOEF manages KETS with the MOE, and MOTIE sets up the national energy plan and electricity supply plan. The ministries have decided on each governmental plan related to climate change and energy in different channels. Although the Korean government has the Committee on Green Growth (CGG) under the Prime Minister's office, the CGG has a low influence and a limited budget to coordinate climate change issues between ministries (Jin \& Kim, 2016: 74). So, a governmental structure change would be one of the alternative options for better coordination and decision-making process.

Some countries have precedents of establishing a comprehensive Ministry responsible for climate change and energy policy together. United Kingdom created the Department of Energy \& Climate Change (DECC) first in 2008, and the DECC had been evaluated positively in terms of consistency and efficiency in policy implementation before its dissolution in July 2016 (Government of UK, 2016). The Australian government had the Department of the Environment and Energy (DEE) between 2016 and 2020, but it was dissolved in February 2020 for the reason of reducing the number of government departments from 18 to 14 (Prime Minister of Australia, 2020). In 2007, the Danish government established the Ministry of Climate, Energy, and Utilities, which was responsible for national and international efforts to prevent climate change in line with energy policy (Danish Ministry of Climate, Energy, and Utilities, 2020).

However, while some countries keep the integrated Ministry, the others changed it back to the previous system. Reasons would vary from a new administration's political decision to a different view of efficiency in climate change issues and the whole government's management. Moreover, the government structure in managing climate change issues does not directly affect public climate finance rise. For example, Japan and Germany have separate Ministries for environment and energy issues (Government of Japan, 2020) (Federal Government of Germany, 2020), but they provide the highest CRDF per ODA (See 〈Table 3〉). Under the integrated Ministry (Government of France, 2020), France's CRDF per ODA is not that high, $12^{\text {th }}$ out of 29 DAC countries (See 〈Table 3〉). Denmark's case is also similar, and its rank is only $14^{\text {th }}$ (See 
$\langle$ Table 3$\rangle$ ). Alternative 3 is acceptable to solve government failure issues, but the impact is questionable to increase climate finance, mainly for developing countries.

\section{5) Alternative 4: Combination of all alternatives}

As a combination of all alternatives, Alternative 4 is a conceptual and ideal option. However, this option could be reviewed because the Office for Government Policy Coordination covers both issues: international development and climate change through the committees: CIDC and CGG. If the Korean government changes the main points from all alternatives, Alternative 4 can solve MF, LCF, and GF to improve Korea's climate finance for developing countries.

\section{Selection of Criteria to Choose among Alternatives}

- Political Feasibility: The extent to which stakeholders accept and support a policy proposal.

- The main stakeholders are the ministries, relevant governmental agencies, and private investors and companies. Because alternatives have a part of structural change between stakeholders, political feasibility is essential. The weight is the highest, 40 out of 100 .

- Administrative Feasibility: The likelihood that a department or agency can implement the policy well.

- All alternatives are complicated in action with various stakeholders. The weight of administrative feasibility is 20 out of 100 .

- Effectiveness: The likelihood of achieving policy goals and objectives or demonstrated achievement of them.

- All alternatives should be reviewed in the view of effectiveness. The weight is 25 out of 100 .

- Efficiency: The achievement of program goals or benefit to the costs, Least costs for a given benefit or the most significant benefit for a given cost. - Efficiency is one of the critical points to compare between policy alternatives. The weight of 15 out of 100 . 


\section{Comparison of Future Consequences}

Through the Criteria Alternative Matrix (CAM), the alternative options are reviewed by criteria (weight): political feasibility (40), administrative feasibility (20), effectiveness (25), and efficiency (15) (See〈Appendix 3〉). Each criterion has a weight based on the importance of drawing a solution in the problem context. Because the primary and influential stakeholders for alternatives are almost the Ministries and public organizations (See〈Appendix 4>), political and administrative feasibility are more critical than the options' effectiveness and efficiency. So, more than half of the weights are assigned to political and administrative feasibility. For instance, political feasibility has the highest weight because alternatives should be accepted first by Ministries. Alternative options require merging or detaching some functions between the Ministries or governmental organizations. Because this change would affect each organization's structure or budget, every Ministry could be quite sensitive to check its benefit or loss from each alternative. Also, there are values with a scale between 1 and 5 to check the extent of criteria in each alternative. After multiplication between the weight and the scale, an alternative could be ranked from the highest points, the sum of the multiplication.

Alternative 1, upgraded status-quo, gets the highest points of 375 and is selected as the best option. Alternative 3, governance change in $\mathrm{CP}$, is calculated as the lowest point of 275. Alternative 2 and 4 are the second and third with the points, 315 and 300, respectively. While Alternative 1 is positively evaluated in political feasibility because there is no significant change in the status-quo, Alternative 4 gets the lowest points due to the government's structural changes in both areas: ODA and CP. For administrative feasibility, changing the government system in Alternative 2, 3, and 4 is quite demanding, but Alternative 1 , status-quo, is easier to handle. In terms of effectiveness, while Alternative 4, a combination of all, gets the highest points ideally, Alternative 1 receives the lowest. Between Alternative 2 and 3, integrating the ODA system, Alternative 2, seems to be more effective because it is the delivery channel of climate finance to developing countries. For efficiency, Alternatives 2, 3, and 4 are better options than Alternative 1 due to decreased transaction costs between stakeholders. 


\section{PROPOSED STRATEGY AND IMPLEMENTATION STEPS}

\section{A Vision of a Desirable Future}

A vision of improving Korea's climate finance is enlarging contribution significantly to prevent climate change and help developing countries adapt to live in a better circumstance. For realizing the vision, specific targets are necessary with a timeline. In 2018, Korea's CRDF and CRDF/ODA were ranked 16th and 22nd largest out of 29 DAC member countries. Considering the amount of $\mathrm{CO}_{2}$ emissions, rated as the 4th largest in the DAC, the Korean government should increase CRDF and CRDF/ODA. As a long-term goal by 2030, the Korean government would set about 30\% CRDF/ODA, the 5th most enormous amount in DAC countries. If the Korean government keeps the target, ODA/GNI, to 0.3\% by 2030, according to the 2nd Framework Plan of International Development Cooperation (Government of Korea, 2015: 4), the amount and impact would be considerable.

\section{Description of the Proposed Strategy}

Upgraded status-quo, Alternative 1, is chosen as the best alternative option from the strategy analysis. Without a profound change in the government, the option seeks to find better ways: raise the efficiency of development agencies in spending CRDF such as KOICA and Korea Eximbank; attract private participation through sharing information and diversifying financial scheme for private investors.

First, the Korean government could make development agencies spend more CRDF. For example, the average proportion of CRDF disbursement by development agencies in Japan, Germany, and France is $88.3 \%$. Also, the average rate of debt instruments by the three countries is 69.0\%. If the Korean government wants to improve efficiency based on the current situation, it could set the goal, similarly with three states: $90 \%$ by development agencies and $70 \%$ with a debt instrument. The baseline of disbursement proportion could be an 
average between 2016 and 2018 under the $2^{\text {nd }}$ Framework Plan of International Development Cooperation. It means that the disbursement proportion by Korea Eximbank will increase from $36.7 \%$ to $70 \%$, and the KOICA's balance will expand from $14.7 \%$ to $20 \%$ (See 〈Table 8$\rangle$ ).

Based on the projection of ODA and CRDF by 2030, in line with a vision and goals: $0.3 \%$ ODA/GNI and 30\% CRDF/ODA, the amounts of CRDF by Korea Eximbank and KOICA in 2030 are 12.7 times and 9.3 times, respectively, larger than the average of 2016-18 (See〈Appendix 5〉).

Second, to realize these goals, the Korean government could make development agencies utilize actively new financial schemes. For example, with accreditation by GCF, KOICA needs to launch a new revolving climate change fund, which can guarantee private investment participation and reinvest benefits from the previous project to the next projects. Also, Korea Eximbank needs to increase not only loans related to climate projects from the government budget but also a new financing method to leverage private climate investment. As the expected leveraging effect of public finance to the private source is a ratio of 1:5 (World Economic Forum, 2013: 7), this strategy could make the Korean government use limited budget efficiently and attract considerable private investment.

〈Table 8〉 Targets of CRDF disbursement by 2030

\begin{tabular}{|c|c|c|c|c|c|}
\hline \multirow{2}{*}{\multicolumn{2}{|c|}{ Organization }} & \multicolumn{2}{|c|}{ Baseline (2016-18 ave.) } & \multicolumn{2}{|c|}{ Target } \\
\hline & & $\begin{array}{l}\text { Proportion } \\
(2016-18)\end{array}$ & $\begin{array}{l}\text { Amount } \\
\text { (mil. \$) }\end{array}$ & $\begin{array}{c}\text { Proportion } \\
\text { (2030) }\end{array}$ & $\begin{array}{l}\text { Amount } \\
\text { (mil. \$) }\end{array}$ \\
\hline \multirow{3}{*}{$\begin{array}{l}\text { Development } \\
\text { agencies }\end{array}$} & Korea eximbank (Debt) & $36.7 \%$ & 138 & $70 \%$ & $1,749.74$ \\
\hline & KOICA (Grants) & $14.7 \%$ & 54 & $20 \%$ & 499.93 \\
\hline & Sub total & $51.4 \%$ & 192 & $90 \%$ & $2,249.67$ \\
\hline Others & Others (Grants) & $48.6 \%$ & 179 & $10 \%$ & 249.96 \\
\hline \multicolumn{2}{|r|}{ Total } & $100.00 \%$ & 371 & $100.00 \%$ & $2,499.63$ \\
\hline
\end{tabular}

Source: Data from OECD DAC and the World Bank, projected by author. CRDF, Climate-Related Development Finance; KOICA, Korea International Cooperation Agency; OECD, Organization for Economic Cooperation and Development. 


\section{Outline of Implementation Steps}

The strategy focuses on spending more public climate finance through development agencies. KOICA and Korea Eximbank need to increase their disbursement for mitigation and adaptation issues, as Japan, Germany, and France did. However, it might not be available without a proper plan and practice. In particular, because this strategy will not change the decentralized ODA system, the Korean government needs to set an additional plan with a specific target of CRDF/ODA based on the $3^{\text {rd }}$ Framework Plan of International Development Cooperation for the period from 2021 to 2025 (See〈Figure 5〉).

After setting plans, the Korean government needs to allow KOICA and Korea Eximbank to increase pilot projects by using a new financial scheme with the private sector. That is an essential part of the implementation steps if the Korean government wants to make the plan succeed. KOICA and Korea Eximbank need more trial and error, and these mistakes should be accepted by the government if there is no wrongful act. Although the Korean government already has an advanced policy concept, many policies are not vitalized as expected. If there is no buffer zone for the new trials, governmental agencies will follow the path-dependent route, rather than seek an innovative way.

In the 4th Framework Plan period between 2026 and 2030, KOICA and Korea Eximbank increase the scale of the project and expand partnership with private investors, applying lessons learned from the period of the 3rd Framework Plan.

〈Figure 5〉 Road to reach target by 2030

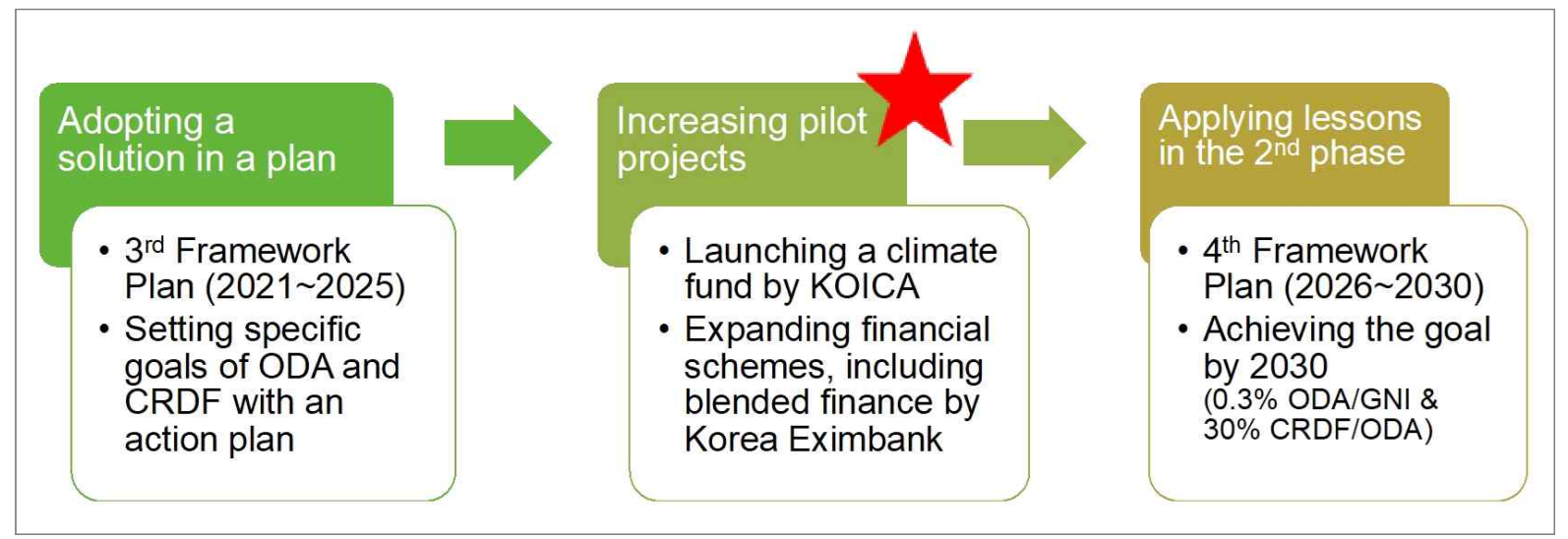

ODA, Official Development Assistance; CRDF, Climate-Related Development Finance; KOICA, Korea International Cooperation Agency. 
Despite the current decentralized ODA system, if KOICA and Korea Eximbank enlarge the project size with an innovative financial scheme, disbursement of CRDF by development agencies could be expanded toward the target without a structural change in the ODA system. This strategy would support to meet the target, $0.3 \%$ of ODA/GNI and 30\% of CRDF/ODA by 2030 .

\section{Provisions for Monitoring and Evaluation}

Regular monitoring and evaluation are critical measures to lead policy for success. The Korean government has regular monitoring and evaluation cycle to check the ODA performance. Every five years, the Korean government verifies ODA's result and prepares the next five-year framework plan at the midterm level. Moreover, an annual ODA implementation plan is established to check each project's progress and allocate a new fiscal year budget. With a more focus on evaluation, the sub-committee of assessment in the CIDC sets an annual plan and execute evaluation for the selected sector and projects.

To improve Korea's climate finance for developing countries, the Korean government needs to use the above-mentioned regular monitoring and evaluation as a practical tool. Besides, it is essential to check various factors with scenarios affecting the results for meeting targets (See〈Table 9〉).

〈Table 9〉 Scenario analysis for optimistic, moderate, and pessimistic conditions

\begin{tabular}{|c|c|c|c|}
\hline \multicolumn{4}{|l|}{ Scenario summary } \\
\hline & Optimistic & Moderate & Pessimistic \\
\hline \multicolumn{4}{|l|}{ Changing cells: } \\
\hline GNI growth rate (\%) & 4.6 & 2.5 & 1.0 \\
\hline ODA/GNI increase rate (\%) & 0.015 & 0.010 & 0.005 \\
\hline CRDF/ODA increase rate (\%) & 1.3 & 0.8 & 0.5 \\
\hline \multicolumn{4}{|l|}{ Result cells: } \\
\hline ODA (million \$) & $8,332.11$ & $5,441.26$ & $3,647.20$ \\
\hline CRDF (million \$) & $2,499.63$ & $1,360.32$ & 802.38 \\
\hline
\end{tabular}

Source: Data from OECD DAC and the World Bank, projected by author.

GNI, Gross National Income; ODA, Official Development Assistance; CRDF, ClimateRelated Development Finance; OECD, Organization for Economic Cooperation and Development. 
The scenario is projected for the next ten years, from 2021 to 2030. The baseline indicators in 2020 are set as $0.150 \%$ of ODA/GNI and $17.0 \%$ of CRDF/ODA due to the data of recent years (See〈Appendix 5$\rangle$ ). The goals, $0.3 \%$ of ODA/GNI and 30\% of CRDF/ODA by 2030, are achievable under the optimistic scenario with $4.6 \%$ of the annual GNI growth rate, which is $0.015 \%$ of the yearly ODA/GNI increase rate, and 1.3\% of annual CRDF/ODA increase rate. The scenario summary shows how ODA and CRDF would be changed in the moderate or the pessimistic scenario.

While the annual GNI growth rate is not controllable, the Korean government could manage both ODA/GNI increase rate and CRDF/ODA increase rate. If the Korean government checks and updates these figures in the regular monitoring and evaluation process, the Korean government could efficiently manage annual contributions against the targets.

\section{Limitations and Potential Unanticipated Consequences}

The Korean government could manage climate finance for developing countries better if development agencies spend more CRDF through adopting new financial measures with the specific target. However, as a traditional limitation, most donor countries may not meet the goal even though they set targets by themselves. For instance, The Korean government missed the self-setting goals twice, $0.25 \%$ by 2015 , and $0.20 \%$ by 2020 .

Also, the considerable challenge comes from an ongoing pandemic, COVID-19. Although both donor and recipient countries face difficulties together, there are more potential casualties in donor countries such as the US and European countries in terms of statistics. Now many states suffer in the worldwide economic downturn. It means that donor countries, including Korea, would lose interest and capacity to support developing countries.

Some scientists said that one of the reasons for pandemic diseases would be climate change, which could destroy wild animals' habitat, and people would have more chances to contact virus-infected animals (Greenpeace, 2020). So, donor countries, including Korea, could have more interest in addressing climate change. However, with public health coming to the forefront of 
policymaking, the priority of climate change issues would most likely fall, and CRDF could be shrunk in the dwindling ODA due to the economic downturn.

\section{CONCLUSION}

To tackle climate change issues for developing countries, the Korean government needs to mobilize more climate finance from three primary resources: ODA, other public sources, and private investment. However, some problems hinder the mobilization of climate finance: bureaucratic failure contributed to the fragmentation of implementation of CRDF from ODA; diffusion of authority in climate change policy implementation limits the government's capacity to manage public climate funds; information asymmetry and the problem of uncertainty hinder private climate investment.

In the strategy analysis, four alternatives are reviewed by four criteria: political feasibility, administrative feasibility, effectiveness, and efficiency. Upgraded status-quo, Alternative 1, is finally selected as a solution. Without a structural change in the government, the alternative seeks to find better ways: raise the efficiency of development agencies such as KOICA and Korea Eximbank in spending CRDF; attract private participation through sharing information and diversifying financial scheme for private investors. Japan, Germany, and France would be good examples to draw the strategy because the three countries are active in mobilizing climate finance globally with various policy options. Moreover, the three countries' ODA structure with relatively high proportions of loans is comparable to Korea's ODA. The Korean government could learn from the three countries' experiences and apply practical measures to improve Korea's climate finance.

This study suggests the Korean government has three implications for improving climate finance for developing countries: setting specific goals in the government plan, implementing new financial schemes for private partners, and managing the whole process by regular monitoring and evaluation.

First, the CRDF spending ratio needs to be on par with Japan, Germany, and France: $90 \%$ by development agencies such as KOICA and Korea Eximbank and $70 \%$ with a debt instrument. To realize this goal, the Korean government needs 
to set a specific target of CRDF/ODA in the 3rd Framework Plan of International Development Cooperation from 2021 to 2025. In a draft of the 3rd Framework Plan, "strengthening response and resilience to climate change" is a strategic objective out of five main objectives. So, the Korean government had better include the goals for CRDF in line with 0.3\% of ODA/GNI and 30\% of CRDF/ODA by 2030. Moreover, the CIDC would assign a CRDF disbursement ratio, $90 \%$ by development agencies, and $70 \%$ with a debt instrument, in an annual ODA implementation plan for every fiscal year.

Second, the Korean government needs to ensure that development agencies actively use new financial schemes such as climate change funds and blended finance. KOICA and Korea Eximbank should increase pilot projects by using a new financial scheme with the private sector. That is the most crucial part of the implementation steps if the Korean government wants to make the plan succeed. KOICA and Korea Eximbank need more "trial and error' opportunities, and these mistakes should be accepted by the government if there is no wrongful act. Although some advanced policy options are identified, the Korean government could not implement policies as expected. If there is no buffer zone for the failure, governmental agencies will follow the path-dependent route rather than seek innovative ways.

Lastly, regular monitoring and evaluation have a pivotal role in checking progress to meet the goals. Also, scenario analysis helps understand the whole picture and factors such as annual GNI growth rate, ODA/GNI increase rate, and $\mathrm{CRDF} / \mathrm{ODA}$ increase rate. While the annual GNI growth rate is not controllable, the Korean government could manage both ODA/GNI increase rate and $\mathrm{CRDF} / \mathrm{ODA}$ increase rate. If the Korean government checks and updates these figures in the regular monitoring and evaluation process, the Korean government could efficiently manage annual contributions against the targets.

\section{REFERENCES}

Agence Française de Développement [AFD]. (2019). Reporting climate bond AFD

2018. Retrieved from https://www.afd.fr/en/reporting-climate-bond-afd-2018 AFD. (2019). AFD's climate-our action. Retrieved from https://www.afd.fr/en/page 
-thematique-axe/climate

Asian Development Bank. (2018). The Korea emissions trading scheme: Challenges and emerging opportunities. Retrieved from https://doi.org/10.22617/TIM18964 $1-2$

Buchner, B., Clark, A., Falconer, A., Macquarie, R., Meattle, C., Tolentino, R., \& Wetherbee, C. (2019, November). Global landscape of climate finance 2019. CPI Report. Retrieved from https://www.climatepolicyinitiative.org/wp-content/upl oads/2019/11/2019-Global-Landscape-of-Climate-Finance.pdf

Byun, K. Y. (2016, July 1). GCF with holds review of the implementation body for the export-import bank. Energy Daily. http://www.energydaily.co.kr/news/article View.html?idxno=71425

Campillo, G., Mullan, M., \& Vallejo, L. (2017). Climate change adaptation and financial protection: Synthesis of key findings from Colombia and Senegal. OECD Environment Working Papers. Retrieved from https://doi.org/10.1787/0b3dc22a-en

Center for Global Development. (2018, September). Environment (Commitment to Development Index 2018). Retrieved from https://www.cgdev.org/commitmentdevelopment-index-2018

Climate Action Tracker. (2019, September). Climate action tracker. Retrieved from https://climateactiontracker.org/

Climate Bond Initiatives. (2018). Korea climate bond market: Overview and opportunities. Retrieved from https://www.climatebonds.net/resources/reports/koreaclimate-bond-market-overview-and-opportunities

Cui, L., \& Huang, Y. (2018). Exploring the schemes for green climate fund financing: International lessons. World Development, 101, 173-187.

Danish Ministry of Climate, Energy, and Utilities. (2020). The ministry. Retrieved from https://en.kefm.dk/the-ministry/

Federal Government of Germany. (2020). Ministries. Retrieved from https://www. bundesregierung.de/breg-en/federal-government/ministries

Federal Ministry for the Environment, Nature Conservation and Nuclear Safety. (2019). IKI funding instrument. Retrieved from https://www.international-climate-initia tive.com/en/about-the-iki/iki-funding-instrument/

G20 Green Finance Study Group. (2016, September). G20 green finance synthesis Report. Retrieved from http://unepinquiry.org/wp-content/uploads/2016/09/Sy 
nthesis_Report_Full_EN.pdf

Germanwatch. (2018, December). Climate change performance index. Retrieved from https://www.climate-change-performance-index.org/

Government of France. (2020). Composition of the government. Retrieved from https://www.gouvernement.fr/en/composition-of-the-government

Government of Japan. (2020). Government directory. Retrieved from https://www. japan.go.jp/directory/

Government of Korea. (2015). 2nd framework plan of international development cooperation 2016-2020. Retrieved from http://www.odakorea.go.kr/ODAPage_2 018/cate02/L01_S01_02.jsp

Government of Korea. (2018). The Korean government's roadmap of GHG mitigation by 2030. Retrieved from http://energytransitionkorea.org/sites/default/files/201 8-11/18.072030-\%E1\%84\%8B\%E1\%85\%A9\%E1\%86\%AB\%E1\%84\%89\%E1\%85\%B5\%E 1\%86\%AF\%E1\%84\%80\%E1\%85\%A1\%E1\%84\%89\%E1\%85\%B3-\%E1\%84\%80\%E1\%85\% A1\%E1\%86\%B7\%E1\%84\%8E\%E1\%85\%AE\%E1\%86\%A8\%E1\%84\%85\%E1\%85\%A9\%E1\% 84\%83\%E1\%85\%B3\%E1\%84\%86\%E1\%85\%A2\%E1\%86\%B8-\%E1\%84\%89\%E1\%85\%A E\%E1\%84\%8C\%E1\%85\%A5\%E1\%86\%BC\%E1\%84\%8B\%E1\%85\%A1\%E1\%86\%AB\%E1\% 84\%80\%E1\%85\%AA\%E1\%86\%AB\%E1\%84\%80\%E1\%85\%A8\%E1\%84\%87\%E1\%85\%AE\% E1\%84\%8E\%E1\%85\%A5-\%E1\%84\%92\%E1\%85\%A1\%E1\%86\%B8\%E1\%84\%83\%E1\%8 5\%A9\%E1\%86\%BC\%20\%281\%29.pdf

Government of UK. (2016). Department of energy \& climate change. Retrieved from https://www.gov.uk/government/organisations/department-of-energy-climatechange

Greenhouse Gas Inventory and Research Center. (2019). Performance report of KETS in the first period 2015-2017. Retrieved from https://www.ctis.re.kr//en/selectB bsNttView.do?key=1576\&bbsNo=314\&nttNo=756980\&searchCtgry=\&searchCnd= all\&searchKrwd=\&pageIndex $=1 \&$ searchBbsType=

Greenpeace. (2020). Scientists warn, climate change drives epidemic spread. Retrieved from https://www.greenpeace.org/korea/update/12074/blog-health-climate -virus/

Gupta, J. (2009). Climate change and development cooperation: Trends and questions. Current Opinion in Environmental Sustainability, 1(2), 207-213.

Han, S., Cho, H., \& Kang, M. (2015). Integration process on the ODA policy- 
making system of Japan: Applying advocacy coalition framework. Korea Social Policy Review, 22(3), 197-234.

International Emissions Trading Association [IETA]. (2016). The world's carbon markets: A case study guide for practitioners (Republic of Korea). Geneva, Switzerland: IETA.

Japan International Cooperation Agency [JICA]. (2020). History. Retrieved from https://www.jica.go.jp/english/about/history/index.html

Jin, I., \& Kim, Y. (2016, November). Policy evaluation on public climate finance of Korea. Retrieved from https://www.nabo.go.kr/Sub/01Report/01_01_Board.jsp? bid=19\&arg_id=6078\&funcSUB=view

Jin, I., \& Kim, Y. (2017, November). Analysis of the role of climate finance for the implementation of the new climate system. Retrieved from https://www.nabo. go.kr/Sub/01Report/03_05_Board.jsp?func=view\&funcSUB=\&currentPageSUB=0 \&pageSizeSUB $=10 \& k e y \_t y p e S U B=\& k e y S U B=\&$ search_start_dateSUB $=\&$ search_en d_dateSUB $=\& a r g \_i d=0 \& b i d=27 \&$ rbid $=0 \&$ ridx $=0 \& b i d S U B=0 \&$ cid $1=0 \& c i d 2=0 \&$ cid 3

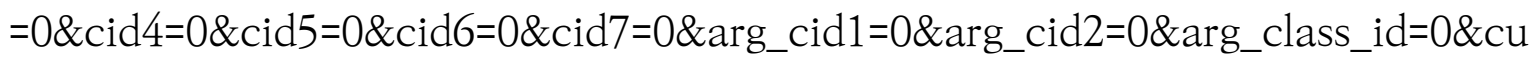
rrentPage=0\&pageSize $=10 \&$ pagePerBlock $=0 \&$ nowBlock $=0 \&$ key_type $=\&$ key $=\&$ sea rch_start_date $=\&$ search_end_date $=\&$ class_id $=0 \&$ sortBy $=\&$ ascOrDesc $=\& b i d x=642$ 8\&idx=6428\&reg_name=\%EC\%A7\%84\%EC\%9D\%B5\%20\%EA\%B9\%80\%EC\%9C\%A4\% ED\%9D\%AC

Kim, S., \& Lee, G. (2019). Research on program model of climate finance by analyzing GCF projects (Research Paper, pp. 1-199). Seongnam, Korea: KOICA. Korean Ministry of Economy and Finance. (2016). ODA utilization plan for development finance. Retrieved from http://www.odakorea.go.kr/hz.blltn2.ODACmtRslt SlPL2.do?brd_seq=24\&blltn_div=oda\#script

KPMG, S. (2018, November). A study of advanced case studies for establishing financial resources and utilization strategies for implementation of the Paris agreement NDC. Retrieved from http://www.prism.go.kr/homepage/entire/retrieveEn tireDetail.do;jsessionid=F4940F927ED4A056653CFBA2B2233346. node02?cond_r esearch_name=\&cond_research_start_date $=\&$ cond_research_end_date $=\&$ researc h_id=1262000-201800066\&pageIndex=34\&leftMenuLevel=160

Ministry of Foreign Affairs [MOFA]. (2015, November 10). Announcement on 2nd framework plan of international development cooperation 2016-20. Retrieved 
from http://www.mofa.go.kr/www/brd/m_4080/view.do?seq=357022\&srchFr=\&a $\mathrm{mp} \% 3 \mathrm{BsrchTo}=\& a \mathrm{mp} \% 3 \mathrm{BsrchWord}=\& a \mathrm{mp} \% 3 \mathrm{BsrchTp}=\& a \mathrm{mp} \% 3 \mathrm{Bmulti}$ itm_seq= 0\&amp\%3Bitm_seq_1=0\&amp\%3Bitm_seq_2=0\&amp\%3Bcompany_cd=\&amp\%3B company_nm=\&page $=269$

Ministry of Foreign Affairs of Japan. (2018, November 1). Joint Crediting Mechanism (JCM). Retrieved from https://www.mofa.go.jp/ic/ch/page1we_000105.html

Moon, J. (2016). Burden-sharing analysis for GHG reduction and climate finance mobilization. Journal of Environmental Policy and Administration, 24(2), 211232.

OECD. (2018a). Climate-related development finance data. Retrieved from http://ww w.oecd.org/dac/financing-sustainable-development/development-finance-topic s/Climate-related-development-finance-in-2018.pdf

OECD. (2018b). Development co-operation report 2018. Retrieved from https:// www.oecd-ilibrary.org/docserver/dcr-2018-en.pdf?expires=1571153694\&id=id\& accname=guest\&checksum $=7987028$ A73E637DE3BA0CAB8F22D30C3

OECD. (2019a). Private Foreign Direct Investment (FDI) from DAC countries to the developing countries. Retrieved from https://stats.oecd.org/qwids/\#? $\mathrm{x}=1 \& \mathrm{y}=6 \& \mathrm{f}$ $=2: 1,3: 51,5: 3,7: 1,4: 64 \& q=2: 1+3: 51+5: 3+7: 1+4: 3,64+1: 2,3,4,5,6,58,7,8,9,10,11,59$, $60,12,13,14,61,15,16,17,18,62,19,63,75,20,21,22,23,24,36, G 2+6: 2008,2009,2010$, 2011,2012,2013,2014,2015,2016,2017

OECD. (2019b, April 10). ODA 2018 detailed summary. Retrieved from https://www. oecd.org/dac/financing-sustainable-development/development-finance-data/O DA-2018-detailed-summary.pdf

OECD. (2020a). Development co-operation profiles. Retrieved from https://www. oecd-ilibrary.org/development/development-co-operation-profiles_2dcf1367-en

OECD. (2020b). Korea: Development co-operation profiles. Retrieved from https://www.oecd-ilibrary.org/sites/d919ff1a-en/index.html?itemId=/content/ component/5e331623-en\&_csp_=b14d4f60505d057b456dd1730d8fcea3\&itemIG $\mathrm{O}=$ oecd\&itemContentType=chapter

Office for Government Policy Coordination. (2013, February). Performance report of East Asia climate partnership (EACP). Retrieved from http://www.odakorea.go. $\mathrm{kr} / \mathrm{hz}$.blltn.domesticReportSl.do?blltn_div=oda\&brd_seq=34\&bltn_seq=25

Office for Government Policy Coordination. (2020). ODA KOREA. Retrieved from 
http://www.odakorea.go.kr/eng.structure.Overview.do

Oliver, P., Clark, A., \& Meattle, C. (2018, November). Global climate finance: An updated view 2018. Retrieved from https://climatepolicyinitiative.org/publication/ global-climate-finance-an-updated-view-2018/

P4G. (2019). 2019 call for P4G partnership applications. Retrieved from https:// p4gpartnerships.org/

Prime Minister of Australia. (2020). New structure of government departments. Retrieved from https://www.pm.gov.au/media/new-structure-government-depart ments

Prime Minister of Korea. (2018). Improvement plan of ODA implementation system. Retrieved from http://www.odakorea.go.kr/hz.blltn2.ODACmtRsltSlPL2.do?brd_s eq=24\&blltn_div=oda\#script

The President of Korea. (2019, September 23). Address by President Moon Jae-in at United Nations Climate Action Summit. Retrieved from http://me.go.kr/hom e/web/board/read.do?menuId=10457\&boardMasterId=744\&boardId=1060760

The World Bank. (2019). World Development Indicators. Retrieved from https://da tabank.worldbank.org/reports. aspx?source=world-development-indicators

United Nations Framework Convention on Climate Change [UNFCCC]. (2015). The Paris agreement. Retrieved from https://unfccc.int/process-and-meetings/theparis-agreement/the-paris-agreement

UNFCCC. (2016). COP 21: Decisions. Retrieved from https://unfccc.int/process-and -meetings/conferences/past-conferences/paris-climate-change-conference-nov ember-2015/cop-21/cop-21-decisions

UNFCCC. (2018). 2018 Biennial assessment and overview of climate finance flows technical report. Retrieved from https://unfccc.int/sites/default/files/resource/ 2018\%20BA\%20Technical\%20Report\%20Final\%20Feb\%202019.pdf

Union of Concerned Scientists. (2020, August 12). Each country's share of $\mathrm{CO}_{2}$ emissions. Retrieved from https://www.ucsusa.org/resources/each-countrysshare-co2-emissions

Wang, G. (2018, June 29). KOICA applied for the Green climate fund implementation organization.. GCF “Quick screening”. Retrieved from https:// www.yna.co.kr/view/AKR20180629073400371

Wang, G. (2019, June 5). KOICA "Responds to global climate change by investing 
100 million dollars". Retrieved from https://www.yna.co.kr/view/AKR201906051 27400371

Weimer, D., \& Vining, A. (2017). Policy analysis: Concepts and practice (6th ed.). New York, NY: Routledge.

World Economic Forum. (2013, January 7). The green investment report: The ways and means to unlock private finance for green growth. Retrieved from https://www.weforum.org/reports/green-investment-report-ways-and-means-u nlock-private-finance-green-growth/ 


\section{〈Appendix 1〉 Socio-ecological model (Improving Korea's climate finance)}

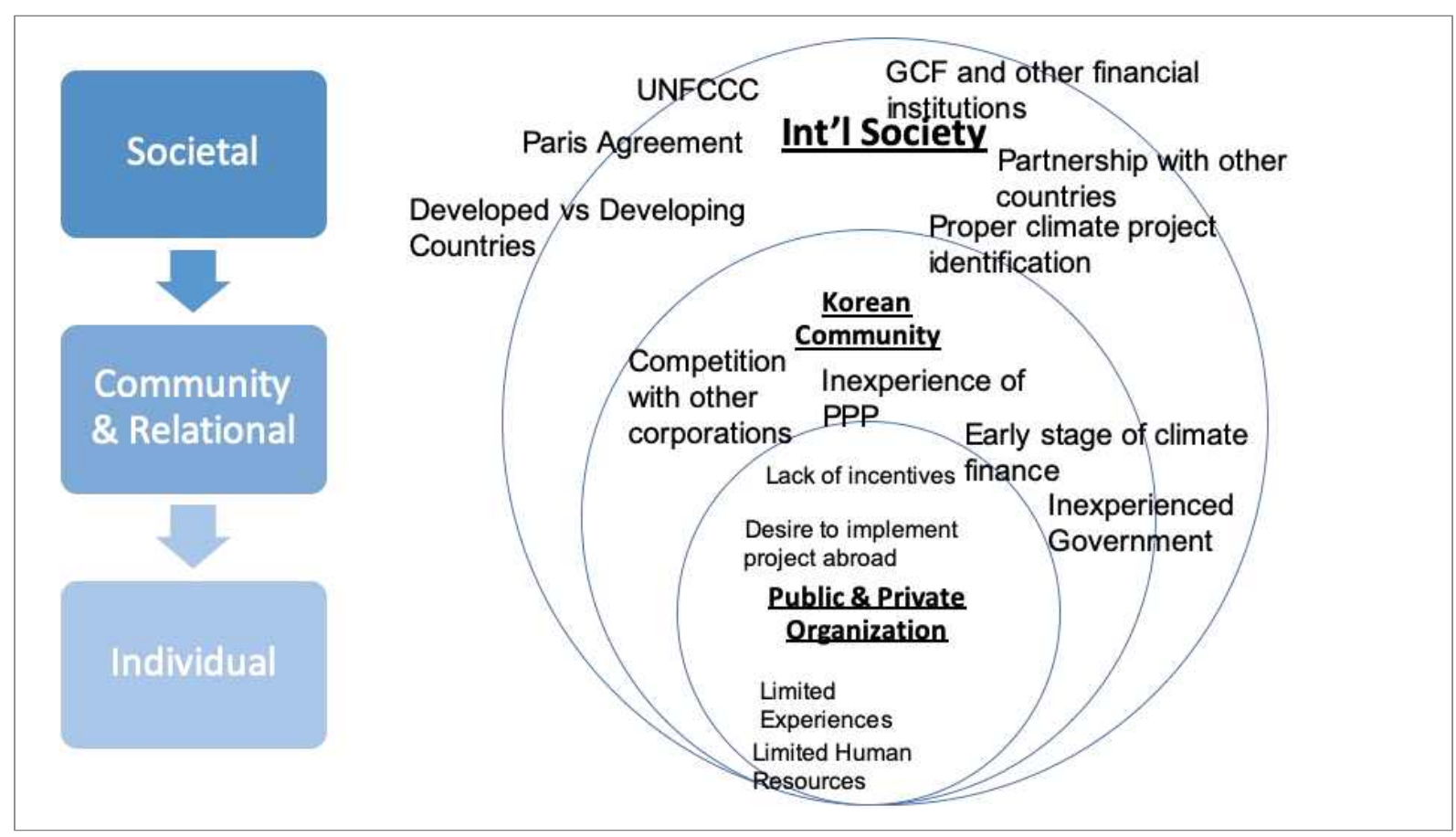

UNFCCC, United Nations Framework Convention on Climate Change; GCF, Green Climate Fund; PPP, Public Private Partnership.

\section{〈Appendix 2〉 Problem tree}

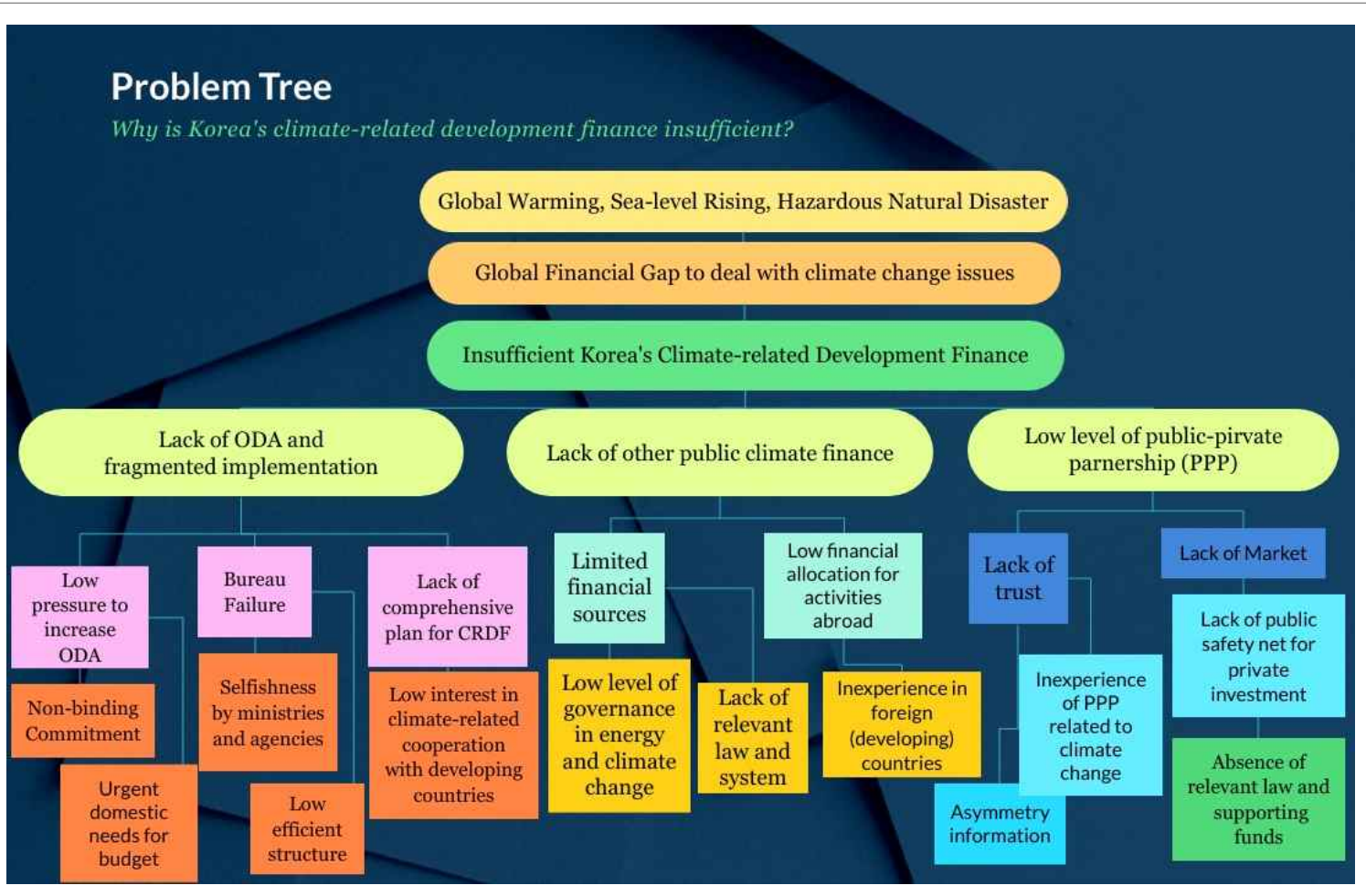

ODA, Official Development Assistance; CRDF, Climate-Related Development Finance . 
〈Appendix 3〉 Criteria alternative matrix

\begin{tabular}{c|c|c|c|c|c}
\hline Criterion & $\begin{array}{c}\text { Weight } \\
(100)\end{array}$ & $\begin{array}{c}\text { 1. Upgraded } \\
\text { Status Quo }\end{array}$ & $\begin{array}{c}\text { 2. Integration } \\
\text { of ODA system }\end{array}$ & $\begin{array}{c}\text { 3. Governance } \\
\text { change in CP }\end{array}$ & $\begin{array}{c}\text { 4. Combination } \\
\text { of all }\end{array}$ \\
\hline $\begin{array}{c}\text { Political } \\
\text { feasibility }\end{array}$ & 40 & 5 & 2 & 2 & 1 \\
\hline $\begin{array}{c}\text { Administrative } \\
\text { feasibility }\end{array}$ & 20 & 4 & 3 & 3 & 3 \\
\hline Effectiveness & 25 & 2 & 4 & 3 & 5 \\
\hline Efficiency & 15 & 3 & 5 & 4 & 5 \\
\hline Total & 375 & 315 & 275 & 300 \\
\hline Ranking & 1 & 2 & 4 & 3 \\
\hline
\end{tabular}

Scale: 1-lowest and 5-highest.

ODA, Official Development Assistance; CP, Climate Policy. 
〈Appendix 4〉 Stakeholder analysis

\begin{tabular}{|c|c|c|c|c|}
\hline Stakeholder & Type & Stakes & Resource/ influence & $\begin{array}{l}\text { Position on } \\
\text { issue }\end{array}$ \\
\hline \multicolumn{5}{|l|}{ Key stakeholders } \\
\hline $\begin{array}{l}\text { Office for } \\
\text { Government } \\
\text { Policy } \\
\text { Coordination } \\
\text { (Prime Minister's } \\
\text { Secretariat) }\end{array}$ & Public & $\begin{array}{l}\text { Better } \\
\text { coordination } \\
\text { among ministries; } \\
\text { effectiveness } \\
\text { between climate } \\
\text { change and } \\
\text { development aid }\end{array}$ & $\begin{array}{l}\text { Head of } \\
\text { decision-making } \\
\text { process, but many } \\
\text { issues driven by each } \\
\text { ministry; less power } \\
\text { to the ministries than } \\
\text { the president office } \\
\text { (Blue House) }\end{array}$ & $\begin{array}{l}\text { Promoter; } \\
\text { high power } \\
\text { /high } \\
\text { interested }\end{array}$ \\
\hline $\begin{array}{l}\text { Ministry of } \\
\text { Economy and } \\
\text { Finance }\end{array}$ & Public & $\begin{array}{l}\text { Burden to allocate } \\
\text { more budget to } \\
\text { ODA }\end{array}$ & $\begin{array}{l}\text { Have an authority for } \\
\text { planning budget of the } \\
\text { Korean government }\end{array}$ & $\begin{array}{l}\text { Neutral; } \\
\text { high power/ } \\
\text { interested }\end{array}$ \\
\hline $\begin{array}{l}\text { Ministry of } \\
\text { Foreign Affairs }\end{array}$ & Public & $\begin{array}{l}\text { Better } \\
\text { international } \\
\text { status of Korea }\end{array}$ & $\begin{array}{l}\text { Coordinating ministry } \\
\text { for grants; cooperation } \\
\text { with UN agencies }\end{array}$ & $\begin{array}{l}\text { Promoter; } \\
\text { high power } \\
\text { /high } \\
\text { interested }\end{array}$ \\
\hline $\begin{array}{l}\text { Ministry of } \\
\text { Environment }\end{array}$ & Public & $\begin{array}{l}\text { Meet the goal of } \\
\text { NDC; reduce } \mathrm{CO}_{2} \\
\text { emissions }\end{array}$ & $\begin{array}{l}\text { Information about } \\
\text { environment and } \\
\text { climate change }\end{array}$ & $\begin{array}{l}\text { Promoter; } \\
\text { high power } \\
\text { /high } \\
\text { interested }\end{array}$ \\
\hline \multicolumn{5}{|l|}{ Primary stakeholders } \\
\hline $\begin{array}{l}\text { Korea International } \\
\text { Cooperation } \\
\text { Agency }\end{array}$ & Public & $\begin{array}{l}\text { More intervention } \\
\text { in climate change } \\
\text { issues; } \\
\text { contribution to } \\
\text { the SDGs }\end{array}$ & $\begin{array}{l}\text { Partnership with } \\
\text { developing countries; } \\
\text { overseas offices over } \\
40 \text { countries; applied } \\
\text { to accredited entities } \\
\text { by GCF (2nd from } \\
\text { Korea) }\end{array}$ & $\begin{array}{l}\text { Promoter; } \\
\text { medium } \\
\text { power } \\
\text { /high } \\
\text { interested }\end{array}$ \\
\hline $\begin{array}{l}\text { The Export-Import } \\
\text { Bank of Korea }\end{array}$ & Public & $\begin{array}{l}\text { Support Korean } \\
\text { companies' } \\
\text { activities with } \\
\text { other countries; } \\
\text { contribution to } \\
\text { the SDGs }\end{array}$ & $\begin{array}{l}\text { Involved in diverse } \\
\text { climate finance } \\
\text { initiatives (green } \\
\text { bond, EDCF (ODA } \\
\text { loans), and a part of } \\
\text { ETS) }\end{array}$ & $\begin{array}{l}\text { Promoter: } \\
\text { medium } \\
\text { power } \\
\text { /high } \\
\text { interested }\end{array}$ \\
\hline $\begin{array}{l}\text { Korea } \\
\text { Development } \\
\text { Bank }\end{array}$ & Public & $\begin{array}{l}\text { Support Korean } \\
\text { companies' } \\
\text { activities with } \\
\text { other countries; }\end{array}$ & $\begin{array}{l}\text { The only accredited } \\
\text { entity by GCF in } \\
\text { Korea; Development } \\
\text { Financial Institute } \\
\text { (DFI) of Korea }\end{array}$ & $\begin{array}{l}\text { Promoter; } \\
\text { medium } \\
\text { power } \\
\text { /high } \\
\text { interested }\end{array}$ \\
\hline
\end{tabular}


$\langle$ Appendix 4〉Continued

\begin{tabular}{|c|c|c|c|c|}
\hline Stakeholder & Type & Stakes & Resource/ influence & $\begin{array}{l}\text { Position on } \\
\text { issue }\end{array}$ \\
\hline $\begin{array}{l}\text { Korean Private } \\
\text { Companies }\end{array}$ & Private & $\begin{array}{l}\text { Expand } \\
\text { investment and } \\
\text { business in } \\
\text { developing } \\
\text { countries }\end{array}$ & $\begin{array}{l}\text { Some networks with } \\
\text { other companies in } \\
\text { developing countries }\end{array}$ & $\begin{array}{l}\text { Promoter; } \\
\text { low power } \\
\text { /high } \\
\text { interested }\end{array}$ \\
\hline $\begin{array}{l}\text { Korean Private } \\
\text { Financial } \\
\text { Institutions }\end{array}$ & Private & $\begin{array}{l}\text { Expand } \\
\text { investment and } \\
\text { make more profit } \\
\text { from the } \\
\text { investment }\end{array}$ & $\begin{array}{l}\text { Resource for FDI; } \\
\text { Private finance for } \\
\text { investment }\end{array}$ & $\begin{array}{l}\text { Promoter; } \\
\text { low power } \\
\text { /high } \\
\text { interested }\end{array}$ \\
\hline \multicolumn{5}{|c|}{ Secondary stakeholders } \\
\hline $\begin{array}{l}\text { Ministry of Trade, } \\
\text { Industry and } \\
\text { Energy }\end{array}$ & Public & $\begin{array}{l}\text { Keep } \\
\text { competitiveness } \\
\text { of Korean } \\
\text { companies; }\end{array}$ & $\begin{array}{l}\text { Direct influence on } \\
\text { Energy issues and } \\
\text { Industry in Korea }\end{array}$ & $\begin{array}{l}\text { Neutral; } \\
\text { high power } \\
\text { / interested }\end{array}$ \\
\hline $\begin{array}{l}\text { Ministry of } \\
\text { Agriculture, Food } \\
\text { and Rural Affairs }\end{array}$ & Public & $\begin{array}{l}\text { Better energy } \\
\text { infrastructure for } \\
\text { farmers; } \\
\text { adaptation issues } \\
\text { in Korea }\end{array}$ & $\begin{array}{l}\text { Some budget to } \\
\text { support farmers and } \\
\text { cooperation with other } \\
\text { countries }\end{array}$ & $\begin{array}{l}\text { Neutral; } \\
\text { medium } \\
\text { power } \\
\text { / interested }\end{array}$ \\
\hline $\begin{array}{l}\text { Ministry of Land, } \\
\text { Infrastructure and } \\
\text { Transport }\end{array}$ & Public & $\begin{array}{l}\text { Energy } \\
\text { management } \\
\text { system for } \\
\text { buildings and } \\
\text { transportation }\end{array}$ & $\begin{array}{l}\text { Information about } \\
\text { sectors }\end{array}$ & $\begin{array}{l}\text { Neutral; } \\
\text { high power } \\
\text { / interested }\end{array}$ \\
\hline $\begin{array}{l}\text { Ministry of } \\
\text { Science and ICT }\end{array}$ & Public & $\begin{array}{l}\text { Strengthen } \\
\text { capacity of } \\
\text { Korean } \\
\text { Technology }\end{array}$ & $\begin{array}{l}\text { Some budget support } \\
\text { for technology } \\
\text { innovation }\end{array}$ & $\begin{array}{l}\text { Neutral; } \\
\text { medium } \\
\text { power } \\
\text { / interested }\end{array}$ \\
\hline \multicolumn{5}{|l|}{ External stakeholders } \\
\hline UNFCCC & Public & $\begin{array}{l}\text { Meet the NDC } \\
\text { goals; more } \\
\text { climate finance }\end{array}$ & $\begin{array}{l}\text { Global Network; } \\
\text { Supervision of NDCs }\end{array}$ & $\begin{array}{l}\text { Promoter; } \\
\text { low power } \\
\text { /high } \\
\text { interested }\end{array}$ \\
\hline UNEP & Public & $\begin{array}{l}\text { Meet the NDC } \\
\text { goals; more } \\
\text { climate finance }\end{array}$ & $\begin{array}{l}\text { Global Network; } \\
\text { Information about the } \\
\text { whole environment } \\
\text { issue }\end{array}$ & $\begin{array}{l}\text { Promoter; } \\
\text { low power } \\
\text { /high } \\
\text { interested }\end{array}$ \\
\hline
\end{tabular}


$\langle$ Appendix 4〉 Continued

\begin{tabular}{|c|c|c|c|c|}
\hline Stakeholder & Type & Stakes & Resource/ influence & $\begin{array}{l}\text { Position on } \\
\text { issue }\end{array}$ \\
\hline $\begin{array}{l}\text { Green Climate } \\
\text { Fund (GCF) }\end{array}$ & Public & $\begin{array}{l}\text { Meet the NDC } \\
\text { goals; more } \\
\text { climate finance }\end{array}$ & $\begin{array}{l}\text { Financial mechanism } \\
\text { to cooperate between } \\
\text { public and private } \\
\text { actors }\end{array}$ & $\begin{array}{l}\text { Promoter; } \\
\text { low power } \\
\text { /High } \\
\text { interested }\end{array}$ \\
\hline $\begin{array}{l}\text { Governments of } \\
\text { Developed } \\
\text { Countries } \\
\text { (ODA Donor } \\
\text { Countries) }\end{array}$ & Public & $\begin{array}{l}\text { Contribution to } \\
\text { SDGs and climate } \\
\text { change issues }\end{array}$ & $\begin{array}{l}\text { Peer review and } \\
\text { pressure; share the } \\
\text { experiences }\end{array}$ & $\begin{array}{l}\text { Promoter; } \\
\text { low power } \\
\text { /high } \\
\text { interested }\end{array}$ \\
\hline $\begin{array}{l}\text { Governments of } \\
\text { Developing } \\
\text { Countries } \\
\text { (ODA Recipient } \\
\text { Countries) }\end{array}$ & Public & $\begin{array}{l}\text { Need more } \\
\text { finance for } \\
\text { development and } \\
\text { climate change } \\
\text { (adaptation) }\end{array}$ & $\begin{array}{l}\text { Influence through } \\
\text { international } \\
\text { agreement like Paris } \\
\text { Agreement }\end{array}$ & $\begin{array}{l}\text { Promoter; } \\
\text { low power } \\
\text { /high } \\
\text { interested }\end{array}$ \\
\hline OECD DAC & Public & $\begin{array}{l}\text { More aid and } \\
\text { activities to solve } \\
\text { development and } \\
\text { climate change } \\
\text { issues }\end{array}$ & $\begin{array}{l}\text { Network among } \\
\text { donors and recipients; } \\
\text { information and data }\end{array}$ & $\begin{array}{l}\text { Promoter; } \\
\text { low power } \\
\text { /high } \\
\text { interested }\end{array}$ \\
\hline $\begin{array}{l}\text { Non-Korean } \\
\text { Companies }\end{array}$ & $\begin{array}{l}\text { Public } \\
\text { /private }\end{array}$ & $\begin{array}{l}\text { More opportunity } \\
\text { to join the } \\
\text { projects }\end{array}$ & $\begin{array}{l}\text { Experiences to } \\
\text { implement projects in } \\
\text { developing countries }\end{array}$ & $\begin{array}{l}\text { Promoter; } \\
\text { low power } \\
\text { /interested }\end{array}$ \\
\hline $\begin{array}{l}\text { Non-Korean } \\
\text { Financial } \\
\text { Institutions }\end{array}$ & $\begin{array}{l}\text { Public } \\
\text { /private }\end{array}$ & $\begin{array}{l}\text { Better profit and } \\
\text { performance from } \\
\text { their investment }\end{array}$ & $\begin{array}{l}\text { Considerable size of } \\
\text { fund and network }\end{array}$ & $\begin{array}{l}\text { Promoter; } \\
\text { low power } \\
\text { /interested }\end{array}$ \\
\hline $\begin{array}{l}\text { International } \\
\text { Environment } \\
\text { NGOs }\end{array}$ & Private & $\begin{array}{l}\text { Reduction of } \\
\text { GHG; better } \\
\text { environment }\end{array}$ & $\begin{array}{l}\text { Advocacy to the } \\
\text { government }\end{array}$ & $\begin{array}{l}\text { Promoter; } \\
\text { low power } \\
\text { /high } \\
\text { interested }\end{array}$ \\
\hline $\begin{array}{l}\text { Universities, } \\
\text { Research } \\
\text { Institutes }\end{array}$ & $\begin{array}{l}\text { Public } \\
\text { /private }\end{array}$ & $\begin{array}{l}\text { Research for } \\
\text { solving climate } \\
\text { change }\end{array}$ & $\begin{array}{l}\text { Introduce new } \\
\text { technology or policy } \\
\text { alternatives to deal } \\
\text { with climate change }\end{array}$ & $\begin{array}{l}\text { Promoter; } \\
\text { low power } \\
\text { /high } \\
\text { interested }\end{array}$ \\
\hline
\end{tabular}

ODA, Official Development Assistance; NDC, Nationally Determined Contribution; GCF, Green Climate Fund; FDI, Foreign Direct Investment; UNFCCC, United Nations Framework Convention on Climate Change; UNEP, United Nations Environment Program; OECD, Organization for Economic Cooperation and Development; NGO, non-governmental organization. 
〈Appendix 5〉 Projection of Korea's ODA and CRDF by 2030

\begin{tabular}{c|c|c|c|c|c}
\hline Year & $\begin{array}{c}\text { GNI } \\
\text { (projected, } \\
\text { mil.\$) }\end{array}$ & $\begin{array}{c}\text { ODA/GNI } \\
\text { (target, \%) }\end{array}$ & $\begin{array}{c}\text { ODA } \\
\text { (projected, } \\
\text { mil.\$) }\end{array}$ & $\begin{array}{c}\text { CRDF/ODA } \\
\text { (target, \%) }\end{array}$ & $\begin{array}{c}\text { CRDF } \\
\text { (projected, } \\
\text { mil.\$) }\end{array}$ \\
\hline 2020 & $1,770,788.95$ & 0.15 & & 17 & \\
\hline 2021 & $1,852,309.35$ & 0.165 & $3,056.31$ & 18.3 & 559.3 \\
\hline 2022 & $1,937,582.64$ & 0.18 & $3,487.65$ & 19.6 & 683.58 \\
\hline 2023 & $2,026,781.59$ & 0.195 & $3,952.22$ & 20.9 & 826.01 \\
\hline 2024 & $2,120,086.92$ & 0.21 & $4,452.18$ & 22.2 & 988.38 \\
\hline 2025 & $2,217,687.67$ & 0.225 & $4,989.80$ & 23.5 & $1,172.60$ \\
\hline 2026 & $2,319,781.59$ & 0.24 & $5,567.48$ & 24.8 & $1,380.73$ \\
\hline 2027 & $2,426,575.52$ & 0.255 & $6,187.77$ & 26.1 & $1,615.01$ \\
\hline 2028 & $2,538,285.85$ & 0.27 & $6,853.37$ & 27.4 & $1,877.82$ \\
\hline 2029 & $2,655,138.89$ & 0.285 & $7,567.15$ & 28.7 & $2,171.77$ \\
\hline 2030 & $2,777,371.41$ & 0.3 & $8,332.11$ & 30 & $2,499.63$ \\
\hline
\end{tabular}

Source: Data from OECD DAC and the World Bank, projected by author.

ODA, Official Development Assistance; CRDF, Climate-Related Development Finance; GNI, Gross National Income; OECD, Organization for Economic Cooperation and Development 